\title{
Attractiveness of Central Public Spaces in Small Polish Towns Based on a Spatial Order Analysis
}

\author{
Wioletta Kamińska *D and Mirosław Mularczyk \\ Institute of Geography and Environmental Sciences, Jan Kochanowski University, 25-406 Kielce, Poland; \\ miroslaw.mularczyk@ujk.edu.pl \\ * Correspondence: wioletta.kaminska@ujk.edu.pl
}

check for updates

Citation: Kamińska, W.; Mularczyk, M. Attractiveness of Central Public Spaces in Small Polish Towns Based on a Spatial Order Analysis. Land 2021, 10, 1327. https://doi.org/ 10.3390/land10121327

Academic Editors: Thomas

B. Randrup, Thomas Panagopoulos, Krystyna Kurowska and

Cezary Kowalczyk

Received: 20 September 2021 Accepted: 29 November 2021 Published: 2 December 2021

Publisher's Note: MDPI stays neutral with regard to jurisdictional claims in published maps and institutional affiliations.

Copyright: (c) 2021 by the authors. Licensee MDPI, Basel, Switzerland. This article is an open access article distributed under the terms and conditions of the Creative Commons Attribution (CC BY) license (https:// creativecommons.org/licenses/by/ $4.0 /)$.

\begin{abstract}
The purpose of this article is to evaluate the attractiveness of centrally located public spaces (main squares) in select new small towns in Poland. The evaluation was conducted from the spatial order perspective. Spatial order is composed of five elements: architectural and urban planning, functional, aesthetic, social, and "green" orders. The new small towns included in this analysis are settlement units, which in 2020 were populated by up to 20,000 inhabitants and received municipal rights in the 21st century. We used the point bonitation method in our research based on the source material collected during a field study. A total of 286 inventory cards of buildings and nine cards of town squares were compiled. The analysis demonstrated that the main squares in the towns studied are characterised by low or average levels of attractiveness from the spatial order perspective. The architectural-urban planning order in the towns in question was related to the number of inhabitants as well as the period over which a given settlement unit had municipal rights. A larger number of inhabitants had a positive influence on the functional diversification of the central squares and their development, whereas a small number limited both the functional diversification and the number of small architectural elements found at the square. The social order in the given towns was not connected to the number of inhabitants. The elements of social order were assessed favourably, both in larger towns that revitalised their central squares and in smaller settlements. The aesthetic and green orders were strongly related to the revitalisation of public space.
\end{abstract}

Keywords: public space; town square; small towns; spatial order; Poland

\section{Introduction}

Public spaces have always been a significant element of urban tissue [1]. Take the Greek agora, the Roman forum, or the Italian piazza as examples. However, as pointed out by Jalaladini and Oktay [2], studies on them have been neglected for a long time, mostly due to the adverse effects of urban planning. Those effects became particularly visible in the 20th century, when towns were built and developed to cater to the needs of growing vehicle traffic rather than to satisfy human needs [2-4]. We should keep in mind that "towns are places where people meet to share ideas, trade or simply rest" [5]. Public spaces are areas of social interactions $[2,6]$. Therefore, in the second half of the 20th century, many urban planners started to take the human dimension of public spaces into consideration [4]. Such a social approach to public spaces focused the scientific debate around actions aiming to increase their attractiveness and, as a consequence, to improve the quality of life for local inhabitants.

Ever since ancient times, public urban spaces have been used for political, military, economic, religious, and sports purposes [7]. Perhaps that is why various authors believe that public space is a basic factor used to confirm the urban character of a place and that a town or city cannot exist without shared, commonly accessible spaces [2,4,8]. Naturally, the forms, arrangement, and functions of public spaces have changed over time $[9,10]$. Nowadays, they are primarily used for leisure purposes [11]. 
Despite its long history, public space has several commonly accepted definitions, which probably resulted from the different perspectives taken by researchers from different fields of science [12] as well as from the diversity of these spaces [13]. For instance, Walzer [14] claimed that public spaces are spaces we share with people we do not know and who are not our relatives, friends, or co-workers, whereas Tibbalds [15] believed that public space is constituted by all parts of urban tissue to which the community has unlimited access. Lorens [16] (p. 83) understood this concept as "a fragment of space which, through the way it is organized and located within the urban structure, is used to enable the participants of social life to communicate directly and to fulfil other social needs of the community, remaining at the same time physically accessible for all those interested".

Many authors stress that public spaces characterise the identity and functions of a settlement unit [17], represent the inhabitants' standard of living, create the town's image, and make it more attractive for tourism, settlement, and investment [18-21].

Public spaces are created by many actors: politicians, self-governing activists, architects and planners, residents, and tourists. Public spaces consist of two subsystems: an urban system-consisting of material, anthropogenic, and natural elements of the town, and a social system-consisting of users of the town and their needs, opinions, and perceptions [8].

From the social point of view, public spaces should be accessible, fair, and safe and should ensure comfort and pleasure [4]. In the literature, we can find concepts of physical and visual accessibility [4]. Physical accessibility enables people to enter public spaces without difficulty and to take advantage of its functions, whereas visual accessibility makes watching everything happening in a given space easier [2]. Fairness of a public space means that it has features such that it can fulfil the needs of various social groups [22]. A safe public space protects its users from physical harm (natural disasters, car accidents, and crime) and also provides them with psychological safety (privacy, and not feeling socially or physically lost) $[2,11,22]$. A properly designed public space should allow a user to walk (walking space, a lack of physical obstacles, good-quality pavements and alleys for walking), sit (zones for sitting and benches to rest on), stand and stay (structures to lean against), look around (reasonable visual distances with open, interesting views and lighting at dusk), speak and listen (low levels of noise), and play and exercise (facilities for physical activity, working out, and playing). The users' pleasure should come from positive sensual impressions (good design and details, beautiful views, trees, plants, and water) [4].

Thus, public spaces should be functionally diversified, i.e., users can perform various activities.

Research on public spaces in towns of different sizes has shown that the accessibility and functionality of these spaces should theoretically be the same or at least similar. In practice, regarding both accessibility and functionality, as well as the aesthetic and ecological aspects, the differences are so large that they form the specific character of public spaces in small towns $[23,24]$. Generally, the accessibility of central public spaces in small towns is better than that in large urban centres due to urban centres being large and heavily populated [25]. Additionally, the level of functionality in public spaces in small towns is lower than that in large and medium-sized towns [26,27].

Although the literature on the subject provides relatively abundant knowledge about public spaces in large cities [28,29] and medium-sized towns [30,31], they are rarely discussed with respect to small towns [23]. We must not ignore the fact that small towns also make up a significant part of national and regional settlement units in many European countries.

For instance, in Poland, in 2019 there were 722 small towns populated by under 20,000 inhabitants, at $22 \%$ of the urban population. After World War II, as a result of dynamic socioeconomic phenomena, small towns underwent multidimensional transformations. Cities with large industrial plants or towns situated close to large factory complexes usually flourished, whereas small, peripheral towns or towns without any sig- 
nificant economic functions fell into states of regression or stagnation [32]. The economic situation had an impact, primarily, on the development and functioning of public spaces. In many small towns, we could observe degradation of the housing tissue and reductions in the functions of public spaces. Only after 1989 (the period of transition from a centrally controlled economy to a market economy and the rebirth of territorial self-government) could we observe a change in attitude towards shaping public spaces in small Polish towns. Local authorities undertook activities aiming to transform the main squares-often devastated and visually unattractive parts of towns-into well-kept areas, satisfying the needs of the local population and revitalising the town. The process was accelerated, on the one hand, due to Poland's accession to the European Union, which provided towns with EU funds for the revitalisation of select spaces, and on the other hand, due to the development of tourism and the resulting necessity to take care of the image of settlement units.

Public spaces may take various forms: a point (an object), a ribbon (a street or the seashore), or an area (a town square or a park). However, in the case of small towns, the town squares have the greatest influence on their identity due to their size and central location. Town squares are where several functions come together: trade, services, housing, administration, and cultural and religious functions [24].

The present spatial order of public spaces is largely related to the historical and economic conditions as well as the demographic potential and location of small urban centres. In towns where the historical (medieval) location of central squares has been preserved, revitalisation, made available with sufficient financial means, helped raise the aesthetic and functional values of the public spaces [33]. In such cases, the old town architecture generally has a positive impact on visual appeal due to the historical heritage of the town square [17]. However, even in such towns, we focus on the limited functionality of buildings, poor aesthetics, and undesirable use of public space (e.g., changing green surfaces into carparks) [17,33].

The relationship between the quality of public spaces in small towns and the level of economic development and location was presented in the study conducted by KoneckaSzydłowska [34]. When studying small towns in the agglomeration of Poznan, she noted that the inhabitants were highly satisfied with the accessibility and functionality of public spaces. This is only natural because a high level of economic development generates high incomes for a given city $[35,36]$, which can be spent on revitalisation and transforming public spaces in accordance with the requirements of a modern society [37-40]. We also stress that people inhabiting small towns situated within the area of influence of huge urban agglomerations are better educated than those in peripheral towns and are more aware of the possibility of satisfying their needs $[36,41,42]$. The pressure exerted on local authorities with regard to shaping public spaces makes it possible to satisfy the expectations of local communities $[25,43]$. On the other hand, towns situated on the peripheries and with a modest population potential have underdeveloped public spaces. They are characterised by low functionality, related to the services used by rural inhabitants rather than by urban inhabitants [44-47]. The public space of such towns is used primarily to accommodate businesses providing basic services $[48,49]$. Additional services occur sporadically, which is natural, because for every settlement unit to develop economically, a minimum population potential is needed: on the one hand, a market, and on the other hand, a work force [50,51].

What is interesting from a cognitive point of view are the changes in the functions and development of the main squares in the settlement units that lost and regained municipal rights (in Poland, a town is a settlement unit that possesses municipal rights, granted administratively by the Council of Ministers. The decision to give a town this status is based on five criteria. The main one is the number of inhabitants. As a rule, a town should have a minimum of 2000 inhabitants. However, in practice, many exceptions to this rule exist. An important exception is having been granted municipal rights in the past. The remaining criteria include the following: at least $60 \%$ of inhabitants must make their living from non-agricultural activity, urban areas of the town should not have farming buildings, a separate centre should be identifiable, and the necessary technical infrastructure, i.e., water 
and sewage systems, should be available). In such towns, the attractiveness of the public spaces is particularly important to inhabitants who typically develop close interpersonal relationships based on their knowledge of places and local communities [21,52].

In light of the remarks above, the purpose of this article is to evaluate the attractiveness of central public spaces (town squares) in select new small towns in Poland. The new small towns presented in the article are settlement units that received municipal rights in the 21 st century and are populated by up to 20,000 inhabitants.

The attractiveness of town squares as public spaces was evaluated in the form of an expert assessment on the basis of direct observations (a field study). The evaluation was made from a spatial order perspective, including five elements: architectural-urban planning, functional, aesthetic, social, and green (ecological) orders. At this stage of the study, the inhabitants' opinions or needs were not considered. These will be the objects of further research.

We assumed that a town square is the town's central square surrounded by buildings [53], which consists of the surface of the town square as well as shared zones, i.e., public streets and pavements running along the edges of the town square, including the accompanying infrastructure [26].

The specific objectives of the article include evaluating the spatial order of the main squares in select new small towns in Poland and rating the architectural-urban planning, functional, social, aesthetic, and green orders, and evaluating the attractiveness of the town squares in select new small towns in Poland.

The article also has a practical purpose. The collected empirical material, if supplemented with the opinions of public space users (inhabitants and tourists) may provide a basis for introducing changes in the spatial order of the town squares in question in order to raise the attractiveness of public spaces in general. In addition, we provide further directions in the research on public spaces in small urban centres.

The results presented below fill the gap in the research on the functions and attributes of public space in units that, for decades, have functioned as rural areas, with predominantly agricultural functions.

\section{Research Area}

The study included nine Polish towns in Świętokrzyskie province (Figure 1), which is one of the few regions in Poland where the rural population is larger than the urban population. It is among the smallest and least developed regions in the country (Eastern Poland), with the lowest socioeconomic development indexes in the whole European Union. In order to decrease the differences between Eastern Poland and the remaining parts of the EU, a special development program was launched (Eastern Poland). Another characteristic feature of the province is a poorly developed settlement network. In 2019, 44 towns, 39 of which were small towns, were populated by under 20,000 people. The number of towns and their sizes in this region are unfavourable. According to research, urban centres have a considerable influence on the economic development of the surrounding rural areas, and the larger the town, the stronger and more widespread the influence [32,51]. Świętokrzyskie province is an example of a region where the development of rural areas is artificially reinforced by granting municipal rights to small settlement units.

The towns in question share several characteristic features. First, they all belong to a group of small (very small) destinations. In 2020, the number of inhabitants ranged from 338 in Opatowiec to 3167 in Radoszyce (Table 1). This group includes the two smallest towns in Poland: Opatowiec and Wiślica (515 inhabitants). Second, all of the settlement units in question have already been given the status of a town in the past. The towns granted municipal rights the earliest (13th century) were Nowy Korczyn, Koprzywnica, and Opatowiec, whereas the one granted municipal rights the latest (16th century) was Daleszyce. Third, all of the destinations in question lost their municipal rights in the 19th century (1869-1870) due to a tsar's edict, as punishment for participating in the January Uprising (at that time, Poland had been partitioned. The towns in question were 
situated in the Kingdom of Poland, which was connected to the Russian Empire due to a personal union).

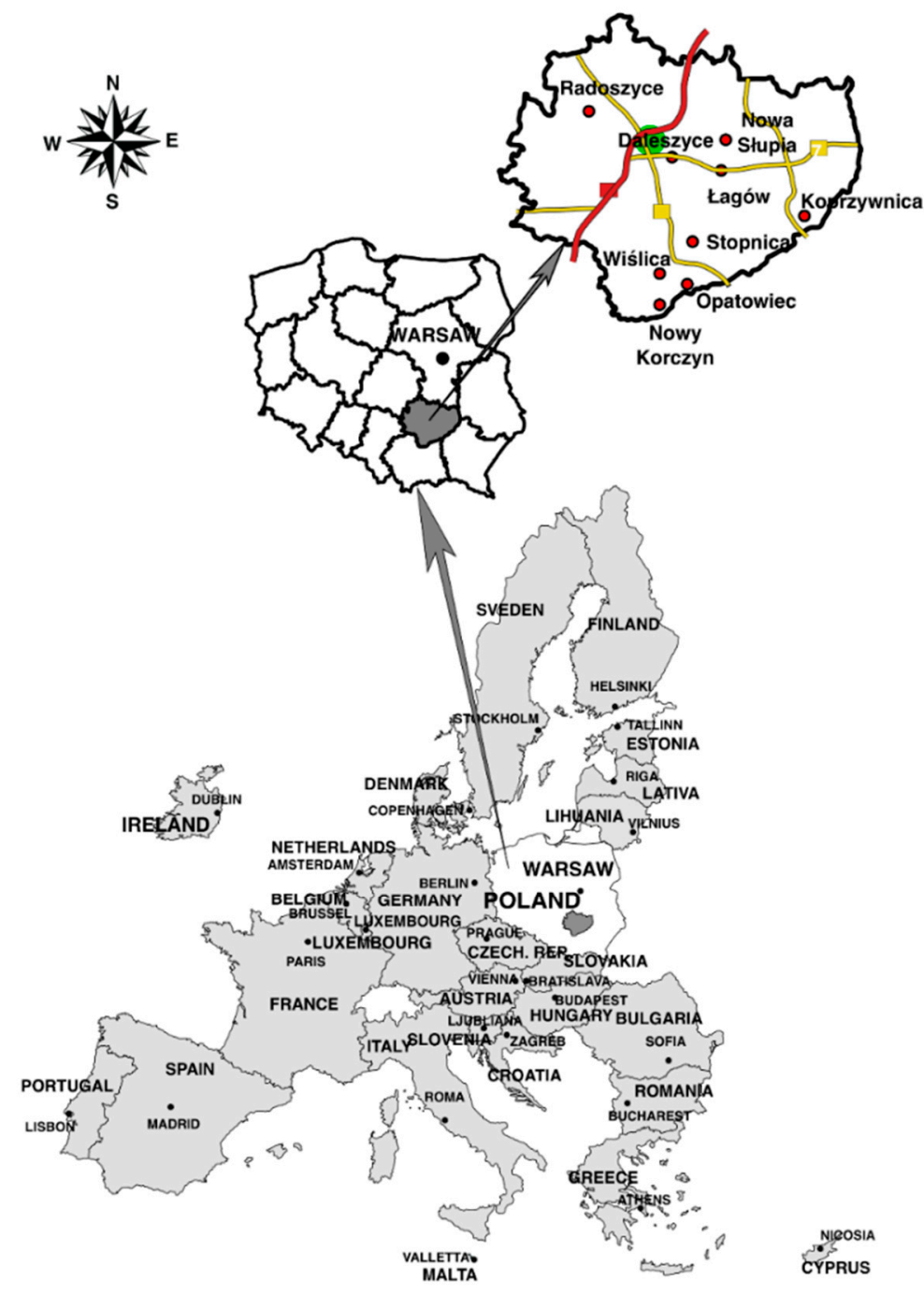

Figure 1. The location of the towns studied in Poland and Świętokrzyskie province. Source: authors' own elaboration.

The studied settlement units functioned as towns for several hundred years. Such a long period enhanced urban features, and the towns developed some functional ties with the vicinity, mostly providing services for their agricultural hinterland [54]. Due to the short distances between them, the towns required services for only a small area, which hampered their growth. Some of them performed other important functions. For instance, Wiślica was a centre for Polish nobility assemblies and Nowy Korczyn was where general councils of Małopolska province started to gather in the 15th century [54]. Nowadays, these places perform mainly administrative and service functions; however, some of them have well-developed tourism (Nowa Słupia and Wiślica).

Another common feature between these settlements is that they regained their municipal rights in the 21st century. First, Daleszyce was reinstated as a town (2007); then, Stopnica was reinstated (2015). The remaining destinations obtained their status as a town in 2018-2019. This means that the majority of the urban units studied have been functioning as towns for only the last three to four years.

It is also worth mentioning that these towns struggle with demographic problems. Since they regained their municipal rights, their population has decreased (a drop by 2-3\%) due to natural loss and migration outflow [32]. The shrinking of the demographic potential 
decreases the level of entrepreneurship, which, in turn, results in smaller incomes and multiple social problems [35]. In addition, population ageing has become evident. In 2020, the percentage of people at the post-productive age (65+) exceeded $20 \%$ in most towns, with the only exception being Daleszyce, where senior citizens made up slightly under $19 \%$. In contrast, in Opatowiec, nearly every third resident was at a post-productive age.

Table 1. Basic information about the studied towns.

\begin{tabular}{|c|c|c|c|c|c|c|}
\hline Town & $\begin{array}{c}\text { Population in the Year } \\
\text { in Which They } \\
\text { Regained Their } \\
\text { Municipal Rights }\end{array}$ & $\begin{array}{l}\text { Population } \\
\text { in } 2020\end{array}$ & $\begin{array}{c}\text { Population } \\
\text { Dynamics (\%) }\end{array}$ & $\begin{array}{l}\text { Period Granted } \\
\text { Municipal } \\
\text { Rights in the } \\
\text { Past }\end{array}$ & $\begin{array}{c}\text { Year in Which } \\
\text { Municipal } \\
\text { Rights Were } \\
\text { Regained }\end{array}$ & $\begin{array}{r}\text { Area } \\
\left(\mathrm{km}^{2}\right)\end{array}$ \\
\hline Daleszyce & 2936 & 2856 & 97.3 & 1569-1869 & 2007 & 15.5 \\
\hline Koprzywnica & 2488 & 2431 & 97.7 & $1268-1869$ & 2018 & 17.9 \\
\hline Łagów & 1587 & 1543 & 97.2 & 1375-1870 & 2018 & 8.2 \\
\hline Nowa Słupia & 1373 & 1356 & 98.8 & 1351-1869 & 2019 & 14.0 \\
\hline Nowy Korczyn & 938 & 904 & 96.4 & 1258-1869 & 2019 & 7.5 \\
\hline Opatowiec & 338 & 336 & 99.4 & $1271-1869$ & 2019 & 5.5 \\
\hline Radoszyce & 3167 & 3095 & 97.7 & $1370-1870$ & 2018 & 17.2 \\
\hline Stopnica & 1455 & 1414 & 97.2 & $1362-1869$ & 2015 & 4.6 \\
\hline Wiślica & 515 & 506 & 98.3 & $1326-1870$ & 2018 & 4.7 \\
\hline
\end{tabular}

Source: date from the Local Data Bank (Central Statistical Office) and provided by town and gmina offices.

\section{Materials and Methods}

This study was divided into three stages: literature review, spatial order analysis, and a catalogue of town squares. The first stage involved studying the literature on the subject: public space planning in small towns, the functions and attributes of public space, and the methods of examining it. Based on the above, the aims of this work and the research questions were formulated.

The second stage involved establishing a set of indicators that define individual elements of the spatial order. The list of indicators was compiled based on the literature review and on discussions with experts about spatial planning, landscape shaping, urbanism, spatial economy, and socioeconomic geography. At this point, our own experiences and reflections as well as our familiarity with the research area were also very helpful. For many years, we have conducted research on various aspects of local and regional developments in Świętokrzyskie province, including the growth of the settlement network and rural areas $[36,51,55]$. We also cooperate with local self-governments and NGOs, designing developmental strategy for rural areas and tourism in this region.

The spatial order perspective was chosen because it allows for a combination of quantitative and qualitative indicators and also creates the possibility to evaluate public space from different points of view.

The attractiveness of town squares is understood as a set of urban planningarchitectural, functional, social, aesthetic, and ecological features, enabling the largest possible group of users to use the public space. The principal method of evaluation was point bonitation, where a certain number of points is ascribed to individual features determining the attractiveness of the public space. Next, the points allocated to individual elements were summed up. The advantage of this procedure is that a synthetic result is obtained, which makes it possible to compare the scores obtained for the main squares in the studied towns. Moreover, this method enables the researchers to assess the features of different titres [56-58] and to run a reassessment based on new criteria, expressed by means of a different bonitation scale [56,59]. However, what often raises doubts is the choice of features and value scales adopted for them, depending on the experts' knowledge, experience, and opinions [56,59]. The point bonitation method has been used in scientific research for the evaluation of tourist attractiveness of spatial units $[60,61]$, natural resources [58,59,62], geodiversity [56], soil quality and varieties [57,63,64], as well as spatial valorisation of land cover and objects of nature protection [65]. It is also referred 
to as [56] rating score [57], bonitation score [63], scoring system [66], or weighting [67,68]. The authors are aware that this method is, to a certain degree, subjective, but this is not uncommon among qualitative methods used in scientific research [61,69-72].

Next, the town square attractiveness index was calculated according to the following formula:

$$
W A=\frac{\text { The number of allocated points }}{\text { Maximal number of points }}
$$

The attractiveness index ranged from 0 to 1 , where 0 signifies the lowest attractiveness (it lacks attractiveness; 0 points within the framework of this research procedure) and where 1 is the highest attractiveness (maximum score). Using its value as a criterion, the authors distinguished town squares of high, medium, and low attractiveness in the following way:

1. $\mathrm{AI} \geq 0.6$ - high attractiveness;

2. $0.4 \leq \mathrm{AI}<0.6$-medium attractiveness;

3. $\mathrm{AI}<0.4$-low attractiveness.

The attractiveness index made it possible to reduce the number of points allocated to the town squares studied for individual types of spatial order to $0-1$ as well as to indicate to what extent the spatial order of public spaces in a given town meets the maximum threshold conditions proposed in this study. A similar technique has been used in scientific research before, bringing positive results [73,74].

It was assumed that spatial order is the structures within the area that form a harmonious whole and takes into account, in orderly relationships, all the architecturalurban planning, functional, social, aesthetic, and ecological conditions and requirements $[16,34,75]$.

It has previously been stated that spatial order consists of five elements.

\subsection{The Architectural-Urban Planning Order}

The architectural-urban planning order is defined by the degree of spatial structural compactness (including residential areas), the cleanliness, the way the buildings are distributed, and their shape and size [76]. Another important aspect is the technical state and the condition of the existing housing tissue, the adopted building convention, the structure and proportions of the buildings, their location in relation to the street, and the colour of the elevations [77-79].

The architectural-urban planning order of the town squares was analysed based on the following elements: the shape and size of the square, the compactness of the buildings surrounding the square, the type of buildings, maintenance of the building alignment, the condition and colour of elevations, the number of overground storeys, and the occurrence of small architectural elements.

In small towns, the main square is densely built up [80]. Therefore, it should have an adequate shape and size. To be design friendly and easily accessible, the town square should have a regular-square or rectangular—shape. According to Gehl [11], its size should ensure the possibility of fulfilling various, often contradictory, needs (e.g., for intimacy and contact with other people, or for peace and quiet as well as fun, at the same time). In order to evaluate the chosen town squares, they were divided into those being regular and irregular in shapes as well as into large, medium-sized, and small squares. Large squares of a regular shape were allocated more points. Under some circumstances, an irregular shape was compensated for by the size of the square. The scores are presented in Table 2.

The next feature assessed was the compactness of residential buildings. A building facing the town square from the front is considered prestigious. Therefore, plots of land in this part of the town are usually among the most expensive. A feature of a well-developed space around the town square is the high density of buildings and a lack of unoccupied plots, which not only has an impact on the visual effect but also creates an opportunity to diversify economic activity. The lack of vacant plots of land is particularly important in 
small towns, as such plots are usually unesthetic and spoil the view of the whole square. We distinguished residential buildings of high, medium, and low compactness (Table 3).

Table 2. Town square shapes and sizes—evaluation criteria.

\begin{tabular}{|c|c|c|}
\hline Town Square Shape & Square Size (Area, Including Streets and Pavements) & Number of Points \\
\hline \multirow{3}{*}{ Regular (square and rectangular) } & Large (over $10,000 \mathrm{~m}^{2}$ ) & 3 \\
\hline & Medium (5100-1000 $\left.\mathrm{m}^{2}\right)$ & 2 \\
\hline & Small (up to $5000 \mathrm{~m}^{2}$ ) & 1 \\
\hline \multirow{3}{*}{ Irregular } & Large (over $10,000 \mathrm{~m}^{2}$ ) & 2 \\
\hline & Medium $\left(5100-10,000 \mathrm{~m}^{2}\right)$ & 1 \\
\hline & Small (up to $5000 \mathrm{~m}^{2}$ ) & 0 \\
\hline
\end{tabular}

Source: authors' own elaboration.

Table 3. Architectural-urban planning order-evaluation criteria.

\begin{tabular}{cccc}
\hline Feature & Compactness & $\begin{array}{c}\text { Criterion (\% of Empty Plots in Relations to the Number of } \\
\text { Buildings along the Town Square Frontage) }\end{array}$ & Number of Points \\
\hline Building & High & No vacant plots & 2 \\
compactness & Medium & $0-20 \%$ of vacant plots & 1 \\
\hline
\end{tabular}

Source: authors' own elaboration.

The next feature taken into account when evaluating the architectural-urban planning order was the type of buildings. The buildings were divided into detached, single-family houses; semi-detached or terraced houses; multi-family houses; and other buildings (e.g., temporary constructions) [78].

Single-family detached houses were rated the best. However, as town squares are space with special, compact structures of buildings, terraced or semi-detached houses should be regarded highly. For this study, we focused on the degree of uniformity between the residential buildings. At the same time, it is worth paying attention to so-called temporary constructions (pavilions, kiosks, and caravans adapted to trading activity). They usually do not look attractive, do not match other buildings, and negatively affect the view of the whole town square. We distinguished between uniform buildings, non-uniform buildings with a small share of temporary constructions, and non-uniform buildings with a large share of temporary constructions (Table 4).

Table 4. Type of buildings-evaluation criteria.

\begin{tabular}{ccc}
\hline Feature & Criterion & Number of Points \\
\hline Uniform buildings & $\begin{array}{c}\text { Over } 60 \% \text { of buildings of the same type } \\
\text { (single-family detached, single-family terraced or } \\
\text { semi-detached, or multi-family) in the total } \\
\text { number of buildings; less than } 5 \% \text { of } \\
\text { temporary constructions }\end{array}$ \\
\hline $\begin{array}{c}\text { Non-uniform buildings with a small share of } \\
\text { temporary constructions }\end{array}$ & $\begin{array}{c}\text { No predominant type of buildings; less than 10\% } \\
\text { of temporary construction in the total number } \\
\text { of buildings }\end{array}$ \\
\hline $\begin{array}{c}\text { Non-uniform buildings with a large share of } \\
\text { temporary constructions }\end{array}$ & $\begin{array}{c}\text { No predominant type of buildings; more than } 10 \% \\
\text { of temporary construction in the total number } \\
\text { of buildings }\end{array}$ \\
\hline
\end{tabular}

Source: authors' own elaboration.

Another important feature is the maintenance of building alignment. An imaginary line demarcates the distance between the building and the frontage border. Local spatial development plans usually impose a binding and impassable building alignment [78]. 
In this study, we refer to the line demarcated by adjacent buildings. Maintaining this alignment has an influence on the aesthetic value of the town square and organises the surroundings (pavements, driveways, etc.) (Table 5).

Table 5. Building alignment and structure-evaluation criteria.

\begin{tabular}{ccc}
\hline Feature & Criteria & Number of Points \\
\hline & $\begin{array}{c}\text { Maintained building alignment (100\% of buildings stand along } \\
\text { one line) }\end{array}$ & 2 \\
\cline { 2 - 3 } Maintaining building alignment & $\begin{array}{c}\text { A curbed line of buildings (two curbs in the whole line of } \\
\text { buildings are accepted) }\end{array}$ & 1 \\
\cline { 2 - 3 } & $\begin{array}{c}\text { The alignment of buildings is not maintained (more than two } \\
\text { curbs in the whole line of buildings around the square) }\end{array}$ & 0 \\
\hline
\end{tabular}

Source: authors' own elaboration.

The next significant feature of the architectural-urban planning order assessed was the condition and colour of buildings' elevations. The state of the building is often related to its age. The front colour, however, is a controversial problem. Although it is generally assumed that flashy colours on buildings are distasteful and disturb the architecturalurban planning order, in recent years, the idea of pastelosis has grown. It was introduced by F. Springer [81], describing negative phenomena in the space of Polish towns and cities. Pastelosis is an effect of the thermal modernisation of Polish houses with the use of Styrofoam, which is later painted with pastel colours. We distinguished four categories of buildings based on their condition and colour (cf. [78]) (Table 6).

Table 6. The condition and colour of buildings' elevations-evaluation criteria.

\begin{tabular}{|c|c|c|}
\hline Feature & Criterion & Number of Points \\
\hline Well-kept and subdued buildings & $\begin{array}{l}\text { Over } 90 \% \text { of buildings were described as well-kept } \\
\text { and subdued; } \\
\text { Up to } 10 \% \text { of buildings were described as neglected } \\
\text { and subdued; and } \\
\text { No buildings were described as flashy, neglected, and } \\
\text { non-uniform. }\end{array}$ & 3 \\
\hline $\begin{array}{l}\text { Relatively well-kept and subdued } \\
\text { buildings }\end{array}$ & $\begin{array}{l}\text { At least } 75 \% \text { of buildings were described as well-kept } \\
\text { and subdued; } \\
\text { Up to } 25 \% \text { of buildings were described as neglected } \\
\text { and subdued as well as flashy, neglected, and } \\
\text { non-uniform. }\end{array}$ & 2 \\
\hline Neglected and subdued buildings & $\begin{array}{l}\text { - Less than } 75 \% \text { of buildings were described as } \\
\text { well-kept and subdued; } \\
\text { At least } 25 \% \text { of buildings were described as neglected } \\
\text { and subdued as well as flashy, neglected, and } \\
\text { non-uniform, with most described as neglected and } \\
\text { subdued. }\end{array}$ & 1 \\
\hline $\begin{array}{l}\text { Very neglected, brightly coloured, } \\
\text { non-uniform buildings }\end{array}$ & $\begin{array}{l}\text { - Less than } 75 \% \text { of buildings were described as subdued } \\
\text { and well kept; and } \\
\text { At least } 25 \% \text { of buildings were described as neglected } \\
\text { and subdued as well as flashy, neglected, and } \\
\text { non-uniform, with most described as flashy, neglected, } \\
\text { and non-uniform. }\end{array}$ & 0 \\
\hline
\end{tabular}

Source: authors' own elaboration.

It is also important to consider uniformity with regard to the height of the buildings standing along the town square frontage, measuring it using the number of storeys. Multistorey buildings around the town square make it possible to diversify functions, which is beneficial both to the owners of the buildings and to the residents. However, from an 
architectural-urban planning order perspective, it is important to achieve uniformity with regard to the height of the buildings. The scores allocated for this feature are presented in Table 7.

Table 7. The diversity in the height of the buildings—evaluation criteria.

\begin{tabular}{|c|c|c|}
\hline Feature & Criterion & Number of Points \\
\hline $\begin{array}{l}\text { Significant number of two- and three-storey buildings } \\
\text { (including a usable attic) }\end{array}$ & Over $75 \%$ of buildings have two or more storeys & 2 \\
\hline $\begin{array}{c}\text { Many two- and three-storey buildings (including a } \\
\text { usable attic) }\end{array}$ & $51-74 \%$ of buildings have two or more storeys & 1 \\
\hline Mostly one-storey buildings & Over $50 \%$ of buildings have one storey & 0 \\
\hline
\end{tabular}

Source: authors' own elaboration.

The last evaluated feature in this order was the number of small architectural elements placed in the town square. These included religious elements (chapels and saints' figures), statues, and utility elements for everyday recreation (sandpits and swings) and for sanitation (litter bins) (Table 8). (According to the Construction Act from 1994 [82], small architectural elements are a set of small construction objects serving area-development purposes. Basic types of small architectural elements include (1) religious cult objects (e.g., chapels, roadside crosses and figures), (2) garden objects (e.g., statues and fountains), and (3) utility objects, for daily recreation (e.g., sandpits, swings, and benches) and for sanitation (e.g., litter bins).) Other small architectural elements are discussed when evaluating the spatial order. The criteria for allocating points were established based on the distribution of features in the towns in question.

Table 8. The occurrence of small architectural elements—evaluation criteria.

\begin{tabular}{ccc}
\hline Feature & Criteria & Number of Points \\
\hline A large number of small architectural elements & 6 or more elements per $1000 \mathrm{~m}^{2}$ of the area of the town square & 3 \\
An average number of small architectural elements & $4-5$ elements per $1000 \mathrm{~m}^{2}$ of the area of the town square & 2 \\
An insignificant number of small architectural elements & 3 elements or fewer per $1000 \mathrm{~m}^{2}$ of the area of the town square & 0 \\
\hline
\end{tabular}

Source: authors' own elaboration.

The total number of points allocated for the architectural-urban planning order ranged from 0 to 18 .

\subsection{The Functional Order}

The second category of the spatial order is the functional order, referring to the comfort of living, and the co-occurrence of various functions and relations among them, such as the occurrence of service, education, and recreation facilities. A properly designed town square should ensure that regular everyday activities (e.g., going to work, to the shop, and to the bus stop), optional activities (e.g., going for a walk and using small architectural elements), and social activities (e.g., having meetings, conversing, and carrying out all kinds of activities) can be performed [11].

In order to evaluate the functional order of town squares in the towns studied, we used the following measures: the number of service outlets per $100 \mathrm{~m}$ of frontage length, the percentage of storeys with higher-order services out of the total number of storeys, the percentage of vacancies out of the total number of storeys, and the ratio of apartments on the ground floor to the total number of buildings. The higher-order services included financial (banking and insurance), legal, advertising, IT, realty, and health care services (doctor and dentist) (cf. [26]). The evaluation criteria were established based on the distribution of individual features in the towns in question (Table 9). The exception was the number of service outlets per $100 \mathrm{~m}$ of frontage length. In this case, the authors used the criteria proposed by Gehl [11]. 
Table 9. Evaluation criteria for the functional order.

\begin{tabular}{|c|c|c|c|}
\hline Measure & Town Square Categories & Evaluation Criteria & Number of Points \\
\hline \multirow{5}{*}{$\begin{array}{l}\text { No. of service establishments per } 100 \mathrm{~m} \text { of } \\
\text { frontage length [26] }\end{array}$} & Attractive & $15-20$ service points per $100 \mathrm{~m}$ & 4 \\
\hline & Pleasant & $10-14$ service points per $100 \mathrm{~m}$ & 3 \\
\hline & "Somewhere in between" & $6-9$ service points per $100 \mathrm{~m}$ & 2 \\
\hline & Boring & $2-5$ service points per $100 \mathrm{~m}$ & 1 \\
\hline & Unattractive & $\begin{array}{l}1 \text { service point per } 100 \mathrm{~m} \text { of } \\
\text { the frontage or no services }\end{array}$ & 0 \\
\hline \multirow{3}{*}{$\begin{array}{c}\text { Percentage of service points in the number } \\
\text { of storeys }\end{array}$} & High & Over $60 \%$ & 2 \\
\hline & Medium & $30-60 \%$ & 1 \\
\hline & Low & Under $30 \%$ & 0 \\
\hline \multirow{3}{*}{$\begin{array}{l}\text { Percentage of places offering higher-order } \\
\text { services in the number of storeys }\end{array}$} & High & Over $10 \%$ & 2 \\
\hline & Medium & $5-10 \%$ & 1 \\
\hline & Low & Under $5 \%$ & 0 \\
\hline \multirow{3}{*}{$\begin{array}{c}\text { Percentage of vacancies in the number } \\
\text { of storeys }\end{array}$} & High & Over $10 \%$ & 0 \\
\hline & Medium & $5-10 \%$ & 1 \\
\hline & Low & Under $5 \%$ & 2 \\
\hline \multirow{3}{*}{$\begin{array}{l}\text { The ratio of ground floor apartments to the } \\
\text { total number of buildings }\end{array}$} & High & Over $33 \%$ & 0 \\
\hline & Medium & $10-33 \%$ & 1 \\
\hline & Low & Under $10 \%$ & 2 \\
\hline Total number of points & & & $0-12$ \\
\hline
\end{tabular}

Source: authors' own elaboration.

\subsection{The Social Order}

The third element of the spatial order is the social order, which refers to individual and collective identification with places and spaces as well as social bonds [83]. It is important that public spaces be accessible without restrictions, ensure safety for their users, and provide all kinds of facilities needed to spend time there and to develop social contacts. The measures and criteria for social order evaluation are presented in Table 10.

\subsection{The Aesthetic Order}

Another element of the spatial order is the aesthetic order. It is the most subjective category, as it refers to the beauty of the town square space. According to Encyklopedia PWN [84], to be aesthetically pleasing means to have a pleasant, stylish look, a sense of beauty. It is difficult to state clearly what "beautiful" means. U. Eco [85] claimed that a beautiful thing is something that makes us happy if it is ours but remains beautiful even if it belongs to someone else. Bierwiaczonek [86] notes that it is commonly assumed that beauty is not what is beautiful but what is attractive to individuals. He adds that what people like usually follows the spirit of contemporary times and the ideal of beauty developed in a given epoch. It can be generally assumed that every culture has its own set of composition rules, shared by a given community [87]. It is often stated in the literature that the aesthetic order depends on the richness of information, cleanliness, and colourfulness, as well as symbols facilitating orientation and skilful navigation [88]. Therefore, in order to evaluate the aesthetic order, we adopted measures defining the level of cleanliness, the aesthetics of advertisements, and the general aesthetic impression of the town square. They were evaluated independently using a seven-degree Likert scale, where 1 signified total neglect, the highest unattractiveness (ugliness) of advertisements, and the highest unattractiveness (ugliness) of the town square space, and 7 meant cleanliness, aesthetic advertisements, and a very attractive square space. We visited the squares studied twice: in the late autumn (end of October 2020) and in the summer (July 2021). The evaluation was based on the mean ratings by two authors on both trips (Table 11). 
Table 10. Measures and criteria for social order evaluation.

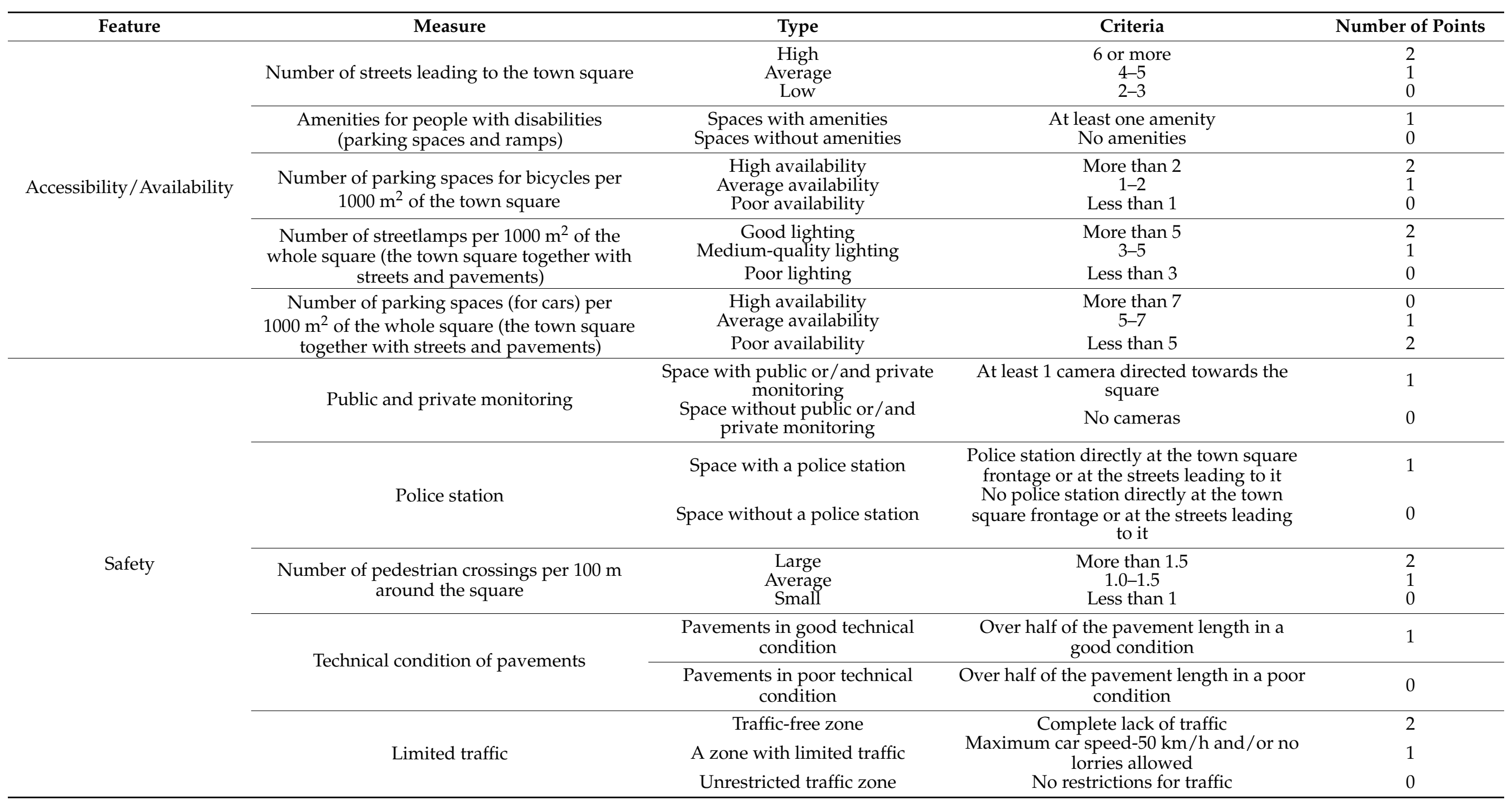


Table 10. Cont.

\begin{tabular}{|c|c|c|c|c|}
\hline Feature & Measure & Type & Criteria & Number of Points \\
\hline \multirow{20}{*}{$\begin{array}{l}\text { Facilities making public } \\
\text { space usable }\end{array}$} & \multirow{3}{*}{$\begin{array}{c}\text { Number of benches per } 100 \mathrm{~m}^{2} \text { of the } \\
\text { town square }\end{array}$} & Large availability & More than 1 & 2 \\
\hline & & Average availability & $0.5-1.0$ & 1 \\
\hline & & Poor availability & Less than 0.5 & 0 \\
\hline & \multirow{2}{*}{$\begin{array}{l}\text { Number of benches in shaded areas per } \\
100 \mathrm{~m}^{2} \text { of the town square }\end{array}$} & Average availability & $0.5-1.0$ & 1 \\
\hline & & Poor availability & Less than 0.5 & \\
\hline & \multirow{2}{*}{$\begin{array}{l}\text { Number of tables per } 100 \mathrm{~m}^{2} \text { of the town } \\
\text { square }\end{array}$} & Large availability & More than 5 & 2 \\
\hline & & Average availability & $\begin{array}{c}1-5 \\
\text { (n) }\end{array}$ & 1 \\
\hline & \multirow{2}{*}{ Gaming facilities (e.g., chess boards) } & Snaces with gaming facilitios & At leact 1 facility & 1 \\
\hline & & Spaces without gaming facilities & No facilities & 0 \\
\hline & \multirow{2}{*}{ Cash dispensers } & Spaces with cash dispensers & At least 1 cash dispenser & 1 \\
\hline & & Spaces without cash dispensers & No cash dispensers & 0 \\
\hline & \multirow{2}{*}{ Public toilets } & Spaces with toilets & At least 1 toilet & 1 \\
\hline & & Spaces without toilets & No toilets & 0 \\
\hline & \multirow{2}{*}{ Outdoor restaurants } & \multirow{2}{*}{$\begin{array}{l}\text { Spaces with outdoor restaurants } \\
\text { Spaces without outdoor } \\
\text { restaurants }\end{array}$} & At least 1 outdoor restaurant & 1 \\
\hline & & & No outdoor restaurants & 0 \\
\hline & \multirow{3}{*}{ Number of walking alleys } & Large & 11 or more walking alleys & 2 \\
\hline & & Average & 6-10 walking alleys & 1 \\
\hline & & Small & Less than 6 walking alleys & 0 \\
\hline & \multirow{2}{*}{ Bike paths } & Spaces with bike paths & At least 1 bike path & 1 \\
\hline & & Spaces without bike paths & No bike paths & 0 \\
\hline Total & & & & $0-28$ \\
\hline
\end{tabular}


Table 11. Evaluation criteria for elements of the aesthetic order.

\begin{tabular}{cccc}
\hline Feature & Type of Town Square & Criteria & Number of Points \\
\hline & Very clean & Mean rating on the Likert scale 7 & 4 \\
Spatial cleanliness & Clean & Mean rating on the Likert scale 6 & 3 \\
& Medium clean & Mean rating on the Likert scale 4-5 & 2 \\
& Dirty & Mean rating on the Likert scale 2-3 & 1 \\
Attractiveness of & Very dirty & Mean rating on the Likert scale 1 & 0 \\
advertisements & High & Mean rating on the Likert scale 6-7 & 2 \\
& Average & Mean rating on the Likert scale 3-4-5 & 1 \\
General aesthetic & Poor & Mean rating on the Likert scale 1-2 & 0 \\
impression & Very nice & Mean rating on the Likert scale 7 & 4 \\
& Nice & Mean rating on the Likert scale 6 & 3 \\
Total & Average & Mean rating on the Likert scale 4-5 & 2 \\
& Ugly & Mean rating on the Likert scale 2-3 & 1 \\
& Mery ugly & & 0 \\
\end{tabular}

Source: authors' own elaboration.

The assessment of elements of the aesthetic order was difficult because it was based on subjective feelings. As one English proverb says, beauty (ugliness) lies in the eye of the beholder. However, in order to be more objective, we adopted the principle that an advertisement is attractive (pretty) if it is not damaged, is legible, and is subdued in colour. An unsightly (unattractive) advertisement is one that is illegible, made unprofessionally (by hand), flashy, and disproportionate in terms of size to the content it presents. If unsightly (unattractive) ads accounted for more than $70 \%$ of their total number, the advertising layer was assumed to be unattractive and 1-2 points were awarded on the Likert scale. In the case when ugly ads accounted for $30-70 \%$ of their total number, the authors allocated $3-5$ points, whereas the share of ugly ads in the total number, being less than $30 \%$, was rated the highest, at 6-7 points. In addition, we investigated the number of advertisements (information chaos), their arrangement, and the uniformity in design (cf. [89]). Similar assumptions were made when assessing the overall aesthetic impression that a square made. In the absence of harmony between individual elements of spatial order, visible neglect of the square (broken benches, littered alleys, rusty parts of fountains, lack of greenery, flowers, etc.) was assessed as very ugly, with 1 point awarded on the Likert scale. Along with the authors' growing positive aesthetic impression, the number of points also increased. This stage of research was the most difficult. When can you say that something is ugly (beautiful)? You know it when you see it (the phrase "I know it when I see it" was used in 1964 by United States Supreme Court Justice Potter Stewart [89]) Beauty is a value that entails harmony, moderation, and balance. It requires abundance but not overload, and simplicity but not meagreness or monotony [90].

\subsection{The Green Order}

The last element of the spatial order in the town squares studied was the green order, referring to valuing the natural environment $[83,91]$. In order to evaluate the green order of the town squares in small towns, we adopted measures related to the size and type of green areas (trees, bushes, and flower beds) and the presence of small architectural elements, such as fountains and small ponds (Table 12). The criteria for allocating points were based on the distribution of individual features in the studied towns. 
Table 12. Criteria in the evaluation of green-order elements.

\begin{tabular}{|c|c|c|c|c|}
\hline Feature & Measure & Types & $\begin{array}{c}\text { Distinguishing } \\
\text { Criteria }\end{array}$ & $\begin{array}{c}\text { Number of } \\
\text { Points }\end{array}$ \\
\hline \multirow{3}{*}{ Tree density } & \multirow{3}{*}{$\begin{array}{l}\text { Number of trees per } 100 \mathrm{~m}^{2} \\
\text { of the town square }\end{array}$} & High & 3 or more & 2 \\
\hline & & Average & 2 & 1 \\
\hline & & Low & 1 or no trees & 0 \\
\hline \multirow{3}{*}{ Shrub density } & \multirow{3}{*}{$\begin{array}{l}\text { Number of shrubs per } \\
100 \mathrm{~m}^{2} \text { of the town square }\end{array}$} & High & 2 or more & 2 \\
\hline & & Average & $1-1.9$ & 1 \\
\hline & & Low & Less than 1 or none & 0 \\
\hline \multirow{3}{*}{$\begin{array}{l}\text { Number of flowers in the } \\
\text { town square }\end{array}$} & \multirow{3}{*}{$\begin{array}{l}\text { Number of flower beds and } \\
\text { pots with flowers per } 100 \mathrm{~m}^{2} \\
\text { of the town square }\end{array}$} & High & 3 or more & 2 \\
\hline & & Average & $1-2.9$ & 1 \\
\hline & & Low & Less than 1 or none & 0 \\
\hline \multirow{3}{*}{ Around-the-house greenery } & \multirow{3}{*}{$\begin{array}{l}\text { Percentage of houses with } \\
\text { flowered lawns or flowers in } \\
\text { front of the house in the total } \\
\text { number of residential } \\
\text { buildings }\end{array}$} & High & $\begin{array}{l}\text { Over } 50 \% \text { of houses } \\
\text { had a representational } \\
\text { flower bed or } \\
\text { flowerpots }\end{array}$ & 2 \\
\hline & & Average & $\begin{array}{l}30-50 \% \text { of houses had a } \\
\text { representational flower } \\
\text { bed or flowerpots }\end{array}$ & 1 \\
\hline & & Low & $\begin{array}{l}\text { Less than } 30 \% \text { of } \\
\text { houses had a } \\
\text { representational flower } \\
\text { bed or flowerpots }\end{array}$ & 0 \\
\hline \multirow{5}{*}{$\begin{array}{l}\text { Water elements (small ponds } \\
\text { and fountains) }\end{array}$} & \multirow{2}{*}{$\begin{array}{l}\text { Presence of a fountain or } \\
\text { small pond }\end{array}$} & $\begin{array}{l}\text { Squares with water } \\
\text { elements }\end{array}$ & $\begin{array}{l}\text { At least } 1 \text { working } \\
\text { fountain or a small } \\
\text { pond }\end{array}$ & 1 \\
\hline & & $\begin{array}{l}\text { Squares without water } \\
\text { elements }\end{array}$ & No water elements & 0 \\
\hline & \multirow{3}{*}{$\begin{array}{l}\text { Technical condition and } \\
\text { purity of water }\end{array}$} & High & $\begin{array}{l}\text { Mean rating on the } \\
\text { Likert scale } 6-7\end{array}$ & 2 \\
\hline & & Average & $\begin{array}{l}\text { Mean rating on the } \\
\text { Likert scale } 3-5\end{array}$ & 1 \\
\hline & & Poor & $\begin{array}{l}\text { Mean rating on the } \\
\text { Likert scale 1-2 }\end{array}$ & 0 \\
\hline Total & & & & $0-11$ \\
\hline
\end{tabular}

Source: authors' own elaboration.

The total of these five elements of public spaces was the basis for the evaluation of their attractiveness in small towns. However, we stress that making a clear classification of all five categories of order is difficult [72]. Some of the measures mentioned above may describe the functional and social, architectural-urban planning, aesthetic, green, social, and functional orders at the same time.

We assumed that all of the features described above are equally important for the spatial order of public space, so we did not diversify them with the use of ranks. This mainly resulted from the fact that public spaces in the studied towns are generally underdeveloped, and some features do not occur at all (e.g., functional elements such as bike paths); diversifying the features by means of ranks was not justified from the point of view of the research process. It should also be noted that the predominant assumption found in the literature on the subject is that all of the components of spatial order are equally important for the functioning of a public space. Without well-developed elements of the urban planning-architectural or social orders, the main squares in small towns would not perform the basic functions of a public space, similar to the ecological and aesthetic orders $[33,34,92]$.

The third stage in the research was a field study, which involved making a detailed catalogue of town squares in the studied towns. The researchers prepared an inventory 
card for each building, including the measures described above (Table 13). They prepared a total of 286 cards of buildings standing along the town square frontage.

Table 13. An inventory card of a building situated along the town square frontage.

\begin{tabular}{|c|c|}
\hline Name of town & \\
\hline \multicolumn{2}{|l|}{ Name of street } \\
\hline \multicolumn{2}{|l|}{ Building number } \\
\hline \multicolumn{2}{|l|}{ No. of overground storeys } \\
\hline Type of building & $\begin{array}{c}\text { Single-family, detached } \\
\text { Single-family, semi-detached, or terraced } \\
\text { Other (office, temporary, etc.) }\end{array}$ \\
\hline Location of the building in relation to the street & $\begin{array}{l}\text { Parallel to the street } \\
\text { Perpendicular to the street } \\
\text { Other }\end{array}$ \\
\hline Location of the building in relation to the main building line & $\begin{array}{l}\text { Maintaining the main building line } \\
\text { Building pushed back from the main building line } \\
\text { Building pushed forward from the main building line }\end{array}$ \\
\hline Functions & $\begin{array}{l}\text { Ground floor } \\
\text { 1st floor } \\
\text { 2nd floor } \\
\text { Other }\end{array}$ \\
\hline
\end{tabular}

Condition and colour of elevations

Age of the building

Type of foundations

Greenery near the house
Well-kept, subdued

Neglected and subdued

Flashy, neglected and non-uniform

Before World War II

After World War II, from the 1990s

New, modern

Stone, unplastered

Stone, plastered

Other besides stone

Representational lawn with flowers in front of the house Single plants

No greenery near the house

Source: elaboration based on [70].

Additionally, all town squares were inventoried, with particular consideration of the small architectural elements, green areas, intensity and aesthetics of advertisements, etc. Nine such cards were prepared (Table 14).

As the next step, the authors evaluated the attractiveness of the squares according to the adopted criteria and formula and, based on this, drew conclusions.

Apart from the point bonitation method and field study, the researchers used the graphic method, which enabled them to present the shapes and sizes of the town squares as well as their functional diversification. 
Table 14. An inventory card of the town square.

\begin{tabular}{lcc}
\hline & Name of Town & \\
\hline Shape of town square & General Information & \\
\hline & $\begin{array}{c}\text { Regular-rectangular } \\
\text { Regular-square } \\
\text { Irregular } \\
\text { Regular-other }\end{array}$ \\
\hline
\end{tabular}

Town square surface

The whole town square area

Length of northside frontage

Town square size (town hall or/and geoportal info)

Length of southside frontage

Length of eastside frontage

Length of westside frontage

Functional Order

Small architecture elements, including religious objects

Utility objects used for everyday recreation

Utility objects for sanitation General aesthetic impression
Chapels (number)

Figures and statues (number)

Other (number)

Climbing frames

Swings (number)

Other (what kind?)

Rubbish bins (number)

Scale 1 (aesthetic)-7 (highly unaesthetic)

\begin{tabular}{|c|c|}
\hline \multicolumn{2}{|c|}{ Social Order } \\
\hline Accessibility & $\begin{array}{c}\text { No. of streets leading to the town square } \\
\text { Amenities for disabled people (parking spaces, ramps, etc.) } \\
\text { No. of parking spaces for bicycles } \\
\text { No. of streetlamps } \\
\text { No. of parking spaces for cars }\end{array}$ \\
\hline Safety & $\begin{array}{c}\text { No. of lamps } \\
\text { General monitoring } \\
\text { Monitoring on private property } \\
\text { Police station in the town square or the streets leading to it } \\
\text { Even and well-kept pavements } \\
\text { Uneven and neglected pavements } \\
\text { Quality of pavements } \\
\text { No. of pedestrian crossings } \\
\text { Traffic restrictions (no car traffic, speed limit, etc.) }\end{array}$ \\
\hline
\end{tabular}

Stage and sound system

Total number of benches

Facilities making it possible to use public spaces

Number of benches in shaded places

Number of tables

Other facilities (e.g., chess boards)

Outdoor restaurants

Identity-related places

Facilities encouraging long stays in public space
Slabs/boulders with plaques commemorating important events Models, photography exhibitions related to the history of the town Other

Working public toilets

No. of outdoor restaurants

Cash dispensers

No. of walking alleys Bike paths 
Table 14. Cont.

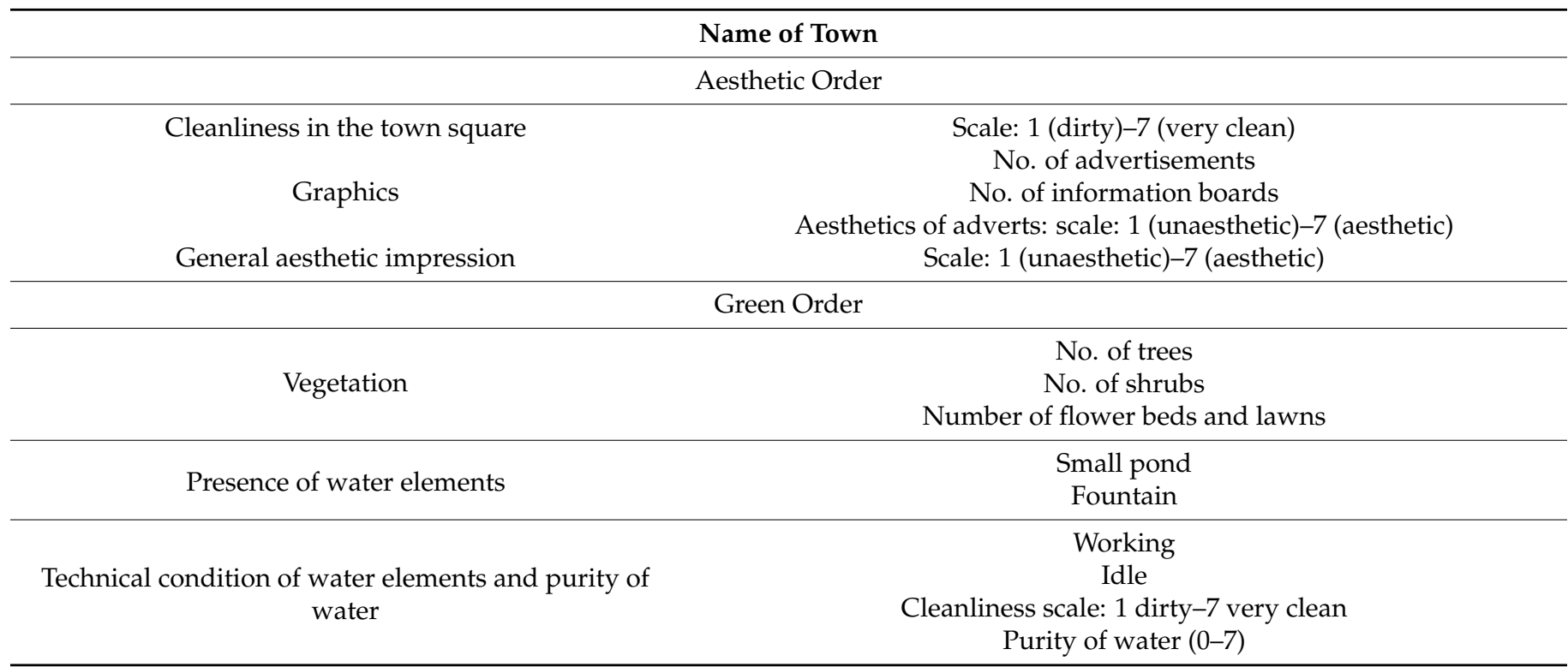

Source: authors' own elaboration.

\section{Results and Discussion}

The overall score for all elements of the spatial order ranged from 26 to 46 points (Table 15), which means that the studied public spaces received $33-58 \%$ of the maximum number of points possible.

Table 15. Points for elements of the spatial order and the town square attractiveness index.

\begin{tabular}{|c|c|c|c|c|c|c|c|}
\hline \multirow[b]{2}{*}{ Town } & \multicolumn{6}{|c|}{ Number of Points for Each Order } & \multirow{2}{*}{$\begin{array}{l}\text { Attractiveness } \\
\text { Index }\end{array}$} \\
\hline & $\begin{array}{l}\text { Architectural-Urban } \\
\text { Planning }\end{array}$ & Functional & Social & Aesthetic & Green & Total & \\
\hline Daleszyce & 11 & 8 & 15 & 8 & 4 & 46 & 0.58 \\
\hline Koprzywnica & 8 & 7 & 9 & 3 & 0 & 27 & 0.34 \\
\hline Łagów & 9 & 7 & 16 & 6 & 7 & 45 & 0.56 \\
\hline Nowa Słupia & 7 & 9 & 7 & 3 & 0 & 26 & 0.33 \\
\hline Nowy Korczyn & 9 & 4 & 18 & 5 & 4 & 40 & 0.50 \\
\hline Opatowiec & 11 & 3 & 8 & 4 & 3 & 29 & 0.36 \\
\hline Radoszyce & 11 & 7 & 14 & 6 & 5 & 43 & 0.54 \\
\hline Stopnica & 12 & 7 & 14 & 7 & 4 & 44 & 0.55 \\
\hline Wiślica & 11 & 6 & 14 & 5 & 6 & 42 & 0.53 \\
\hline
\end{tabular}

Source: authors' own elaboration.

\subsection{The Architectural-Urban Planning Order}

The score for all elements of the architectural-urban planning order ranged from 7 to 12 points. The maximum number of points was 18 (Table 15), which means low and medium levels of this order were found for the analysed towns. The highest number of points was allocated to the town square in Stopnica (Figure 2), a destination that regained its municipal rights only six years ago. The town square there has a regular shape, close to a square, and its area (together with streets and pavements) covers over $7000 \mathrm{~m}^{2}$, which places it among medium-sized town squares. The square in Stopnica was allocated 12 out of 18 points ( $67 \%$ of the maximum score). The smallest number of points was allocated to the town square in Nowa Słupia, which has an irregular shape and a small area, slightly over $6000 \mathrm{~m}^{2}$. It regained it municipal rights in 2019. Generally speaking, the town square in this town was neglected with respect to the architectural-urban planning order. The only highly rated feature was the type of buildings. They were mostly uniform buildings, 
with few temporary structures. The remaining features were rated poorly, particularly the compactness of the buildings, the condition and colour of the elevations, and the occurrence of small architectural elements. The researchers allocated seven points to this square ( $39 \%$ of the maximum square).

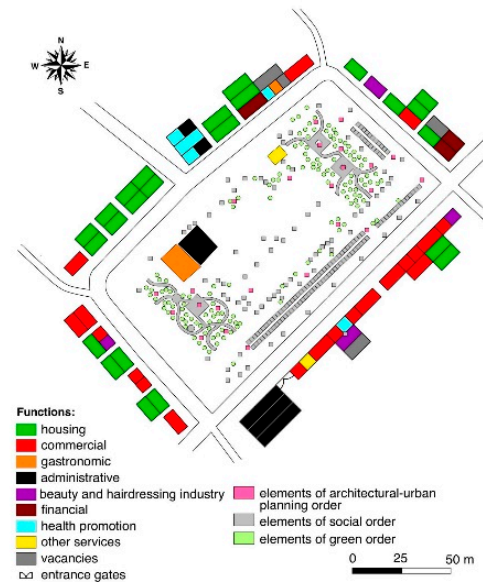

4

"荻紧
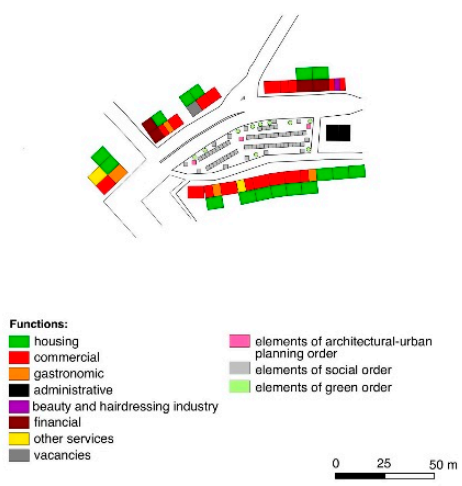

7

“荻炎

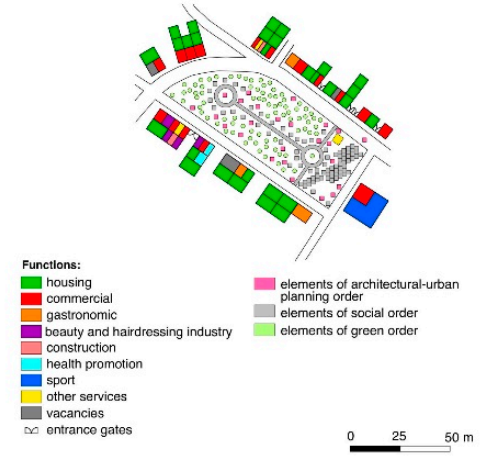

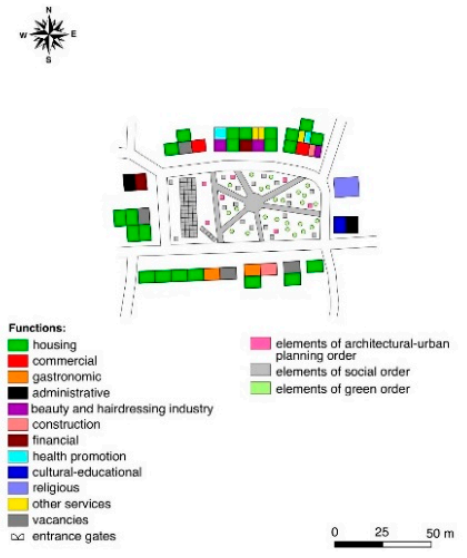

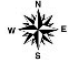
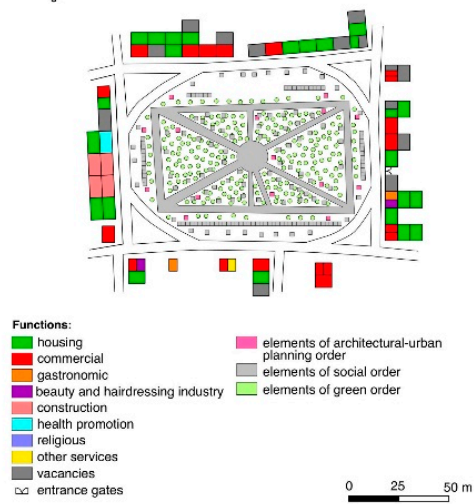

8

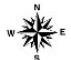
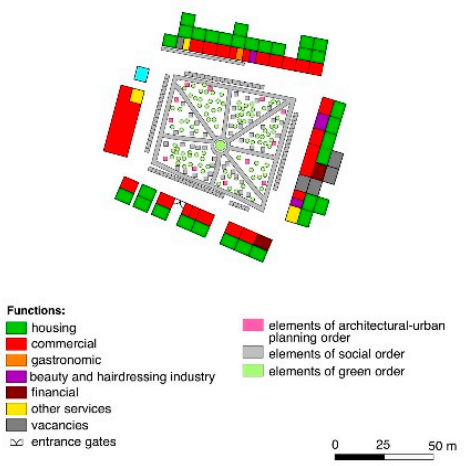

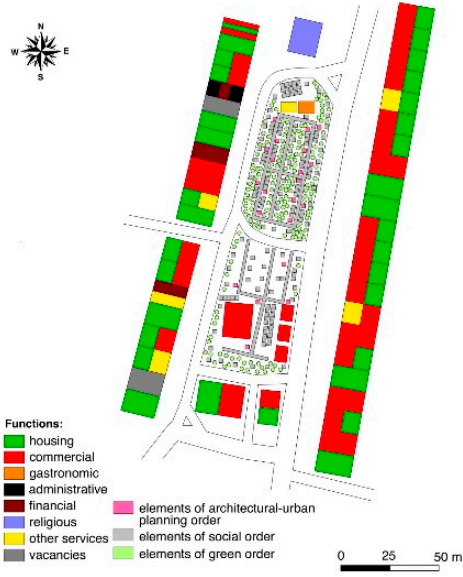

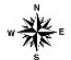
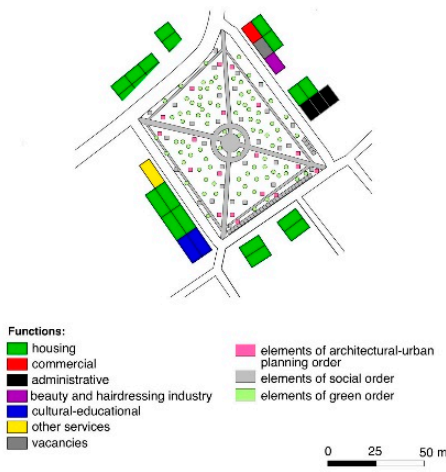

9
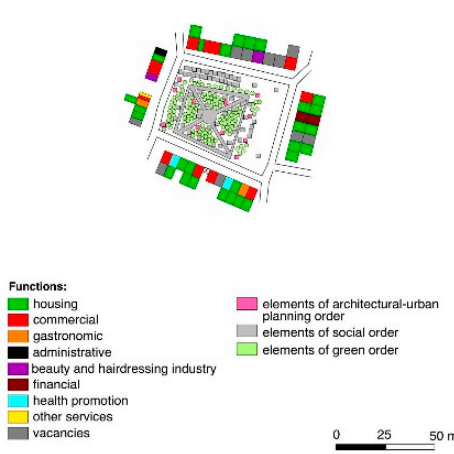

Figure 2. Selected elements of the spatial order of town squares in new small towns. Source: authors' own elaboration. 1-Daleszyce, 2-Koprzywnica, 3- Łagów, 4-Nowa Słupia, 5-Nowy Korczyn, 6-Opatowiec, 7—Radoszyce, 8-Stopnica, 9-Wiślica. 
Generally speaking, town squares in the studied towns are regular in shape; the majority of them are small and medium-sized. Only two towns-Daleszyce and Łagówhave rectangular squares of impressive sizes. Both towns were granted subsidies for revitalisation, transforming these spaces according to current trends. The areas of the squares exceed $20,000 \mathrm{~m}^{2}$.

The weaknesses of all of the town squares were the low compactness of the buildings and large number of undeveloped plots. These weaknesses are convergent with the results of studies conducted by other authors, stressing the insufficient use of space near central squares in small towns [26]. The compactness of the buildings is additionally reduced by drive-in gates, which often disrupt the whole space. Another drawback is the poor state and faded or motley colours of building facades. In nearly all cases, many buildings were neglected and brightly painted, not matching the surroundings. Regrettably, this phenomenon is often stressed in the literature and can be found in the public spaces of towns of different sizes [16]. The amount of small architectural elements was also rated poorly (Figure 2). Only in individual cases could we find figures or statues in the square (in Stopnica, 2; in Daleszyce, 2; and in Wiślica, Nowy Korczyn, Łagów, and Opatowiec, 1). Most pieces of small architecture were for sanitation (litter bins), but they were scarce in the public spaces studied, which has been confirmed by the observations made by other researchers regarding the development of public space in small Polish towns $[8,37,39,93,94]$. The number of small architectural elements found in town squares is connected to the historical past. They are represented by statues of historical figures and figures of saints, showing people's attitude regarding the Catholic Church and Christian faith. In the towns in question, even historical events are presented in conjunction with characters related to Catholic Church. Czepczyński [8] called this a sacralisation of public spaces and claimed that it is the most pronounced and dynamic socio-spatial process observed in many small towns. They also indicated that many elements of this type are historical and related to the activity of previous generations. Small architectural elements also point to the modern use of financial resources, which are spent to cover the cost of revitalisation (e.g., introducing elements used to maintain cleanliness).

The low evaluation of the architectural-urban planning order is closely connected to the age of the buildings. Many were built before World War II, and the majority were erected in the socialist period (1945-1989), with only a few appearing at the turn of the 21st century. During central planning, the appearances of buildings were not a priority and there were shortages of basic construction materials or finishing elements (external fittings, window and door woodwork, glazing, balustrades, cladding, plasters, and paint coatings) [95]. It is mainly such houses that surround the main public spaces in these towns. The loss of their municipal rights deepened the economic crisis, and in no way did it help to recreate the housing tissue. The age of buildings is also related to the number of storeys. Those built before World War II usually have one storey, e.g., temporary and provisional constructions (pavilions and kiosks). The buildings erected during the centrally planned economy period usually have two storeys, and new buildings have two storeys and a usable attic. Similar features were observed in small towns located in other regions of Poland [17]. The state of the buildings surrounding the squares also worsened due to migration processes. Young people are migrating to larger centres, and those who stay are older and cannot afford to redecorate their houses. It is generally an unfavourable situation because, as Jacobs [3] (p. 29) said, "If a city's streets look interesting, the city looks interesting; if they look dull, the city looks dull."

\subsection{Functional Order}

The score for the functional order ranged from three to nine points (Table 15). The maximum number of points to be calculated was 12 , which means that the studied public spaces received $25-75 \%$ of the maximum number of points. Thus, it can be stated that the functional order in the studied towns was at the low and medium level (Table 15, Figure 2). The highest number of points (9) was allocated to the town square in Nowa Słupia, a 
destination situated on the edge of Świętokrzyski National Park, which concentrates most tourist traffic to the Holy Rood Monastery, an important place in the province and in Poland from historical and religious points of view. From the 13th to the early 19th century, the town was the property of the Holy Rood Benedictine Abbey. For centuries, it developed infrastructure providing services to tourists, which caused a relatively high functional diversification and enabled a large number of establishments to adapt to service functions. The smallest number of points was allocated to Opatowiec (three points) - the least populated town in the country. The buildings standing along the town square frontage did not develop any other function except for the residential one.

The weakness of the functional order of the squares in the studied towns was the generally small functional diversification. The predominant function was trade (5-50\% of the overall number of storeys). The shops were usually small groceries or markets, where one can buy all kinds of goods, from toiletries and household chemicals to metal objects and household equipment. It was more typical of rural areas than towns, even small ones. Higher-order services (financial, healthcare, cultural-educational, legal, and advertising) were rare, and they did not occupy more than $11 \%$ of the total number of storeys (in most towns, it was 2-5\%). A similar phenomenon has been identified by other researchers in various regions of Poland. This is typical of small Polish towns [26]. What is also worrying is the high percentage of vacancies in the buildings surrounding the town square. For instance, in Nowy Korczyn, every fourth storey showed no signs of being used, and in Wiślica, nearly every fifth one. Apart from the fact that they do not have a utility value, vacancies also have neglected elevations and woodwork and, generally, make a bad impression.

The lack of functional diversification makes public spaces boring and not attractive to the inhabitants. Holland et al. [96] found that people are attracted and usually stay longer in public spaces that offer excitement, stimulation, and some comfort. A particularly negative factor affecting the functioning of the town squares in the studied towns is the lack of gastronomic establishments. As indicated by Whyte [97], nothing attracts people to a public space as effectively as the possibility to eat and drink, and a person having a meal in a public space attracts even more people. The town square as a central place should be a concentration of a variety of services. The towns in question have not developed a rich functional structure, remaining rural units. The shrinking population does not encourage the town to expand their service offer.

\subsection{Social Order}

The score for the social order in the towns analysed ranged from 7 to 18 points. The maximum number of points was 28 (Table 15), which means that the studied public spaces received $25-64 \%$ of the maximum number of points. Thus, the social order in the towns studied was also at the low and medium levels. The highest number of points was allocated to the town square in Nowy Korczyn (Figure 2). The town regained its municipal rights in 2019. The whole square has a small area, but many elements, as well as their accessibility and safety for various social groups, have been taken care of. However, it must be stressed that, although many elements function within the space of the square, their availability is definitely insufficient. If we take amenities for people with disabilities, for example, there are parking spaces in the square but only two. According to the regulations [98], there should be a minimum of three such spaces. (The number of parking spaces for people with disabilities in Poland is specified by the Public Roads Act of 21 March 1985 [98]. This number depends on the total number of parking spaces in a given carpark. When a lot has six to 15 parking spaces, one should be reserved for people with disabilities. However, in carparks with 16-40 spaces, a minimum of two spaces must be designated for people with disabilities. In carparks where the total number of parking spaces is 41-100, a minimum of three parking spaces should be dedicated to this group of people. If there are more than 100 parking spaces, $4 \%$ of them must be reserved for people with disabilities. There are 70 parking spaces at the square in Nowy Korczyn.) The lowest 
number of points was allocated to the squares in Nowa Słupia (7) and Opatowiec (8). None of them follow the basic rules of social order, and they do not encourage developing interpersonal relationships. In Nowa Słupia, almost the whole space of the square is used as a parking lot. Similar management approaches have been defined as inappropriate and were also observed in other regions of Poland $[17,33,37,39]$. Research shows that areas dedicated to car traffic decrease the vitality of public spaces [99]. There are no walking alleys, trees, shrubs, or small architectural elements. A similar situation was observed in Opatowiec. There is inadequate lighting on the square and an insufficient number of pedestrian crossings. There are also no public toilets, ATMs, restaurant gardens, or other elements attracting the inhabitants of the town.

Generally, another weakness of all of the town squares under study was a lack of facilities and elements that would not only attract the inhabitants but also make them stay longer. People tend to stay within public space if they find comfortable seats there, with some kind of protection against bad weather [2]. The small number or complete lack of gastronomic establishments, lack of public toilets or limited access to them, and lack of outdoor restaurants do not enhance the vitality of public spaces. During revitalisation, trees and shrubs were nearly completely removed from the two largest town squares in Łagów and Daleszyce. Despite later attempts, it was impossible to restore the former greenery. As a result, the number of benches in shaded places decreased, which is particularly important, as the majority of the towns' inhabitants are senior citizens.

\subsection{Aesthetic Order}

The score for the aesthetic order in the towns analysed ranged from three to eight points. The maximum number of points was 10 (Table 15), which means that the studied public spaces received $30-80 \%$ of the maximum number of points. The highest number of points was allocated to Daleszyce, which is a destination situated closest to the main city of the province, Kielce, and was the first to regain its municipal rights among the towns in the study (2007). This is important because the town could take advantage of Polish and European funds for revitalisation. From an aesthetic point of view, the town looks very impressive, it is very clean, and the problem of unattractive advertisements is under control.

The lowest rated for aesthetics were the town squares in Koprzywnica and Nowa Słupia. These squares are characterised by an excessive number of advertisements and signboards. They are poorly made, often heavily weathered, and cause information chaos. In Koprzywnica, there are over 10 adverts and signboards per $100 \mathrm{~m}$ of square frontage length. The cobbled town square in Nowa Słupia, which has no flowers or greenery, is filled with cars and has practically no strolling or relaxing people in view, and does not have a high degree of spatial order according to this study. Previous research has shown that spaces designed for traffic decrease the vitality of public spaces $[6,100]$. In addition, as stressed by Jacobs [3] and by Jalaladini and Oktay [2], the decreasing significance of pedestrian traffic in urban public spaces makes them dehumanised and lowers the quality of life for the inhabitants.

\subsection{Green Order}

The score for the green order in the towns analysed ranged from zero to seven points. The maximum number of points was 11 (Table 15), which means that the studied public spaces received $0-64 \%$ of the maximum number of points. The largest number of points was allocated to the town square in Łagów (Figure 2). It is one of the largest squares in the whole province, revitalised in 2013 for nearly half a million PLN (about EUR 120,000). Similar to the majority of revitalised town squares in Poland, in the second decade of the 21st century, nearly all trees and shrubs were cut down and the whole surface of the two square was paved. However, for several years, there have been attempts to restore green surfaces, and in the case of Łagów, it has been partly successful. Unfortunately, the destruction of greenery in public spaces in small Polish cities has virtually become a regular 
feature of these spaces. Many authors emphasise this negative aspect of shaping central squares in small towns $[37,39]$. The town square in Nowa Słupia, which is practically devoid of greenery, was allocated zero points for green order (Figure 2).

In Nowy Korczyn, Nowa Słupia, and Pokrzywnica, a lack of greenery was noted outside residents' homes $(90 \%, 87 \%$, and $77 \%$, respectively). Such numbers must be regarded as highly influential on the overall green order of the towns and, therefore, as a weakness in terms of the overall spatial order.

\subsection{Attractiveness of the Town Squares}

Taking the attractiveness index values into consideration, the town squares in the towns analysed can be divided into two groups: squares of medium and low attractiveness. The first group includes the squares in Daleszyce, Łagów, Nowy Korczyn, Radoszyce, Stopnica, and Wiślica, where the attractiveness index ranged from 0.50 to 0.58 . This means that those squares scored about half of the maximum score. This group contains two categories of squares. The first one includes revitalised squares, with well-designed social and aesthetic orders but imperfect green order (Daleszyce (Figure 3), Łagów (Figure 3), Stopnica (Figure 3), and Wiślica (Figure 3). Revitalisation included a good design of the town square and small architectural elements, such as some amenities promoting social contacts (tables, gaming equipment, etc.). The other category encompasses squares that have not been revitalised yet, where natural greenery has not been damaged. In these towns, town squares are characterised by city parks. Due to the number of inhabitants and historical conditions, they have high-quality social and architectural-urban planning orders, which eventually raised the value of the attractiveness index by over 0.5 . This category includes the town squares in Radoszyce and Nowy Korczyn.

The other group, consisting of unattractive squares (low attractiveness index, less than 0.4), includes the town squares in Opatowiec, Koprzywnica, and Nowa Słupia. These spaces do not have attributes of urban public spaces. None of the elements of social order have been fully developed.

The characteristic features of these squares include small functional diversity, lack or small number of amenities enhancing social contacts (tables, game boards, walking alleys, and benches), insufficient greenery, poor aesthetics of the frontage buildings, and small area of the central public space.

Public spaces in small towns, which used to be villages just a few years ago, do not seem to be attractive. This seems to be the main cause of the low quality of all attempts at renovation of these spaces. The projects often do not consider the history of the town, its identity, or the needs of its inhabitants. They duplicate previously prepared projects for other towns of similar sizes (and similar numbers of inhabitants) [101]. A lack of stable traditions and models of creating central spaces in small towns lowers their attractiveness. The physical forms of these towns loosely refer to the wishes and needs of the local communities [2]. Watson et al. [102] indicated that town squares shaped in this way do not have a clear, specific character and are only a mixture of styles and themes borrowed from different parts of Poland and the world. Perhaps this uniform pattern of urban spaces results from the fact that such a concept turned out to be a success in the struggle for EU funds, and other local government units, wanting to increase their chances in this race, follow these "good models" [39].

It should also be noted that the results obtained depend, to a large extent, on the method and measures adopted. The bonitation method used in the study and the concept of spatial order allowed us, on the one hand, to assess the attractiveness of the squares of small towns in Poland from a broad perspective, using a rich and varied set of measures. This approach should be assessed positively. On the other hand, the study used a number of qualitative measures that require subjective assessment by researchers (e.g., measures describing the aesthetic order of public space). This means that the results may vary depending on the personality traits of the researchers (e.g., aesthetic feelings, emotional state, and weather conditions). 
1

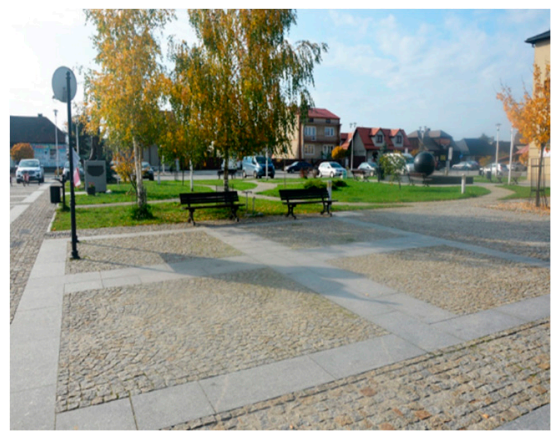

4

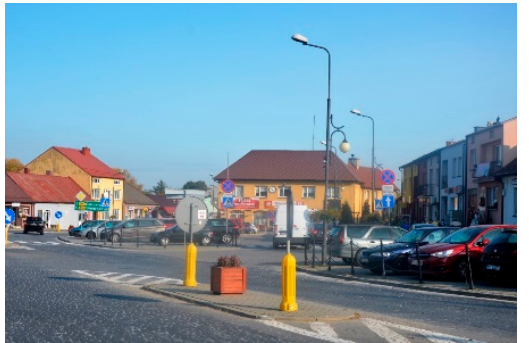

7

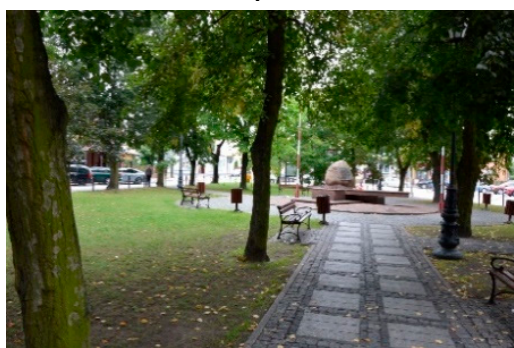

2

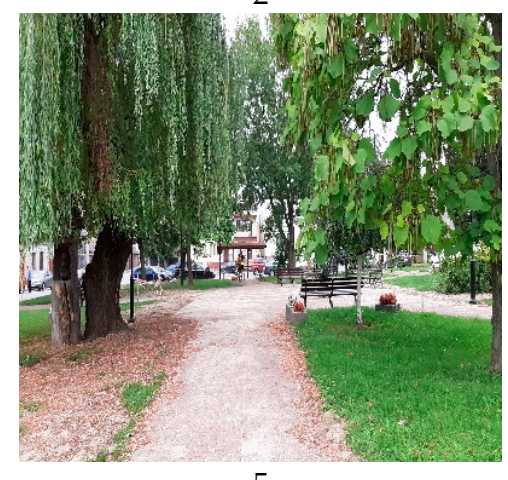

5

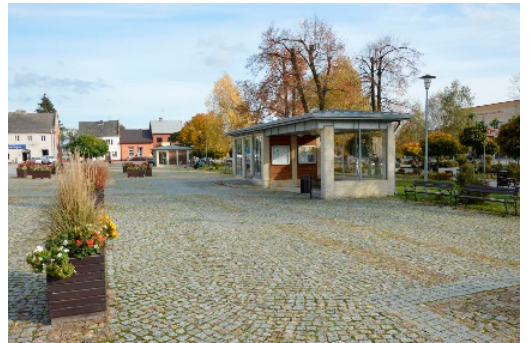

8

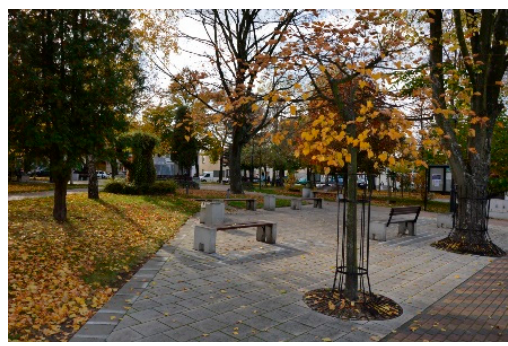

3

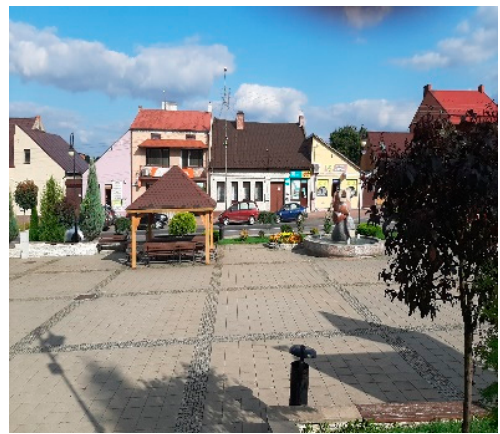

6

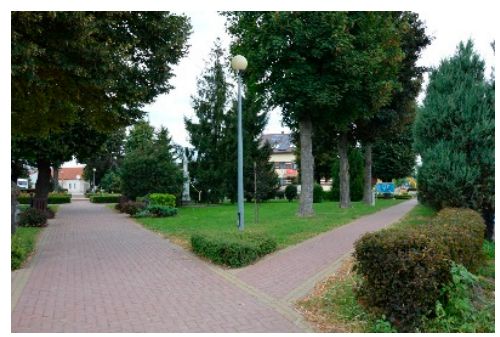

9

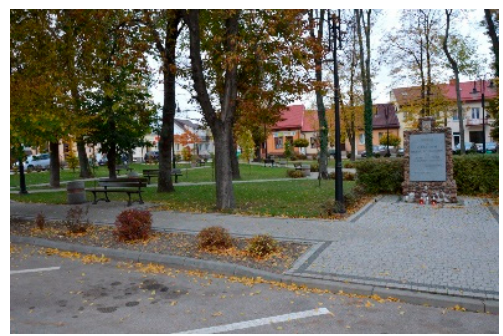

Figure 3. Town squares. Source: authors' own work. 1-Daleszyce, 2-Koprzywnica, 3—Łagów, 4-Nowa Słupia, 5-Nowy Korczyn, 6-Opatowiec, 7-Radoszyce, 8-Stopnica, 9-Wiślica.

\section{Conclusions}

The analysis shows that the town squares in the towns studied represent low or medium levels of attractiveness, if seen from the perspective described in this study. This means that the attributes of urban public spaces have been poorly developed. The most attractive squares were the main squares of the largest towns, which regained municipal rights the earliest (Daleszyce, Łagów, and Stopnica). Those towns were able to use the financial means they received for the revitalisation of their squares, and their relatively large population enhanced the functional development of public spaces. Their weakness is in the shortage of green areas, resulting from common revitalisation trends, such as transforming squares from green to paved areas.

The town squares of the settlement units that were granted municipal rights over the last two to three years are usually small in area, and poorly equipped with small architectural elements or places where the inhabitants can meet. Their characteristic features include large green areas, weak functional diversification, and low buildings along the square frontage. These town squares are green decorations in the towns rather than meeting places and local event venues. The small population potential, the ageing population, many years of neglect of the housing substance, and limited interpersonal relations have caused the poor functional development of these squares and the disappearance of generally accepted aesthetic models. These towns do not meet the basic criteria of urbanity (a small population) and will not be able to develop a public space with the features described in the literature review. 
In our evaluation, the lowest-rated square was the town square in Nowa Słupia. All of the elements of spatial order differed from the other destinations. It is a space devoid of public space attributes. The town square is a former marketplace, which gradually turned into a carpark, along with the development of tourist functions. For such a square to gain a basic function as a public square, it needs a complete transformation.

In transforming public squares, it is important to note that a public space must be designed to answer the inhabitants' needs and should reference the history and identity of the town. Revitalised town squares may not look the same in all small towns.

The considerations presented concern settlement units that functioned as villages several years ago. Gaining municipal rights in the 21st century created new challenges, both for the inhabitants and the local authorities. One such challenge is the creation of friendly public spaces that represent the town and is a place for social relations.

Based on the analysis of individual elements of the spatial order of town squares in new small towns, the following can be concluded:

1. The architectural-urban planning order in the towns in question was related to the number of inhabitants as well as the period over which a given settlement unit had municipal rights. A larger number of inhabitants (over 1000) had a positive influence on the functional diversification of the central squares and their development (e.g., Daleszyce, Radoszyce, and Stopnica), whereas a small number limited both the functional diversification and the number of small architectural elements found at the square (e.g., Nowy Korczyn, and Opatowiec). Moreover, in towns with a relatively large number of inhabitants, we observed a larger-than-average number of developments of higher-order services (legal, healthcare, and financial) compared to all of the settlement units under study. Those that were granted municipal rights the earliest (six to 14 years ago) managed to reshape their public spaces using EU and domestic funds for revitalising central squares (e.g., Daleszyce and Stopnica) better than the youngest towns (e.g., Opatowiec and Nowy Korczyn). The number of small architectural elements in the squares represented the history of the towns as well as the predominant Christian religion. The small new towns showed clear symptoms of public space sacralisation. The weakness of the architectural-urban planning order was the poor compactness of buildings situated along the square frontages as well as their poor technical conditions. The low compactness resulted mainly from the low value of the plots at the square and the lack of spatial development plans. This mostly concerned the smallest towns, situated peripherally in Świętokrzyskie province, that gained their municipal status in the last two to three years (Koprzywnica, Opatowiec, and Nowy Korczyn). The poor technical conditions of the buildings standing along the square frontage resulted from their age (the majority were built before and right after World War II and from the relatively low financial status of the ageing community), which is now urban but was still rural two to three years ago. The lack of financial resources for repairs fostered permanent degradation of the housing tissue.

2. The social order in the towns studied was not related to the number of inhabitants. The authors rated the elements of the social order in both larger towns that revitalised their squares (Daleszyce, Łagów, and Radoszyce) and in small settlement units that had not started renovations on their public spaces (Nowy Korczyn and Wiślica) highly. Smaller settlement units have a rich history connected to organising noblemen's meetings and general assemblies as early as the 14th century (cf. Section 2). Perhaps the resulting traditions contributed to preserving old amenities and to creating new amenities connected to shaping social relationships.

3. The aesthetic and green orders were largely related to the revitalisation of public spaces. The towns that already revitalised their central squares, liquidating natural greenery and paving the square's surface (e.g., Łagów and Daleszyce), presented high ratings for aesthetic order but low ratings for green order. In those towns, the authorities attempted to revive green areas in public space, but the effects were not always satisfactory. In towns where revitalisation had not yet taken place (e.g., 
Koprzywnica and Opatowiec), the green order of the central squares (natural green complexes) was highly rated, whereas their aesthetic order was rated poorly. The assessment of both orders in towns where central squares had been turned into carparks (e.g., Nowa Słupia) without natural greenery was rated poorly.

4. Creating a friendly public space (according to the requirements presented in the introduction) in small new towns, especially those situated peripherally in agricultural areas, requires time, financial means, vision, and engagement on the part of the local authorities, non-governmental organisations, and the inhabitants.

The research presented here is the first stage in the evaluation of the attractiveness of town squares in new small towns in Świettokrzyskie province. This attractiveness was evaluated from the researchers' point of view. The next stage should include evaluations of these public spaces from the users' perspectives (considering their mental comfort, and physical and hydrothermal existence within public space) as well as the perspectives of formal planning and management organisations (local authorities and politicians). This will make it possible to compare the technical results from this study with the governanceoriented aspects of planning and development for public squares using a technical approach with the opinions of public space users.

The material presented in this article can be used for comparisons by other researchers and practitioners who deal with similar issues. The results of this study may be applicable to small towns in other countries of Central and Eastern Europe that used to belong to the Eastern Block and had similar conditions of socioeconomic development.

Author Contributions: Conceptualisation, W.K. methodology, W.K.; software, W.K. and M.M.; validation, W.K. and M.M.; formal analysis, W.K.; investigation, W.K.; resources, W.K. and M.M.; writing W.K.; visualisation, W.K. and M.M.; supervision, W.K.; funding acquisition, W.K. and M.M. All authors have read and agreed to the published version of the manuscript.

Funding: This research was funded by Jan Kochanowski University in Kielce, Poland.

Institutional Review Board Statement: Not applicable.

Informed Consent Statement: Not applicable.

Conflicts of Interest: The authors declare no conflict of interest. The funders had no role in the design of the study; in the collection, analyses, or interpretation of data; in the writing of the manuscript; or in the decision to publish the results.

\section{References}

1. Stanley, B.W.; Stark, B.L.; Johnston, K.L.; Smith, M.E. Urban open spaces in historical perspective: A transdisciplinary typology and analysis. Urban Geogr. 2012, 33, 1089-1117. [CrossRef]

2. Jalaladdini, S.; Oktay, D. Urban Public Spaces and Vitality: A Socio-Spatial Analysis in the Streets of Cypriot Towns. Procedia Soc. Behav. Sci. 2012, 35, 664-674. [CrossRef]

3. Jacobs, J. The Death and Life of Great American Cities: The Failure of Modern Town Planning; Random House: New York, NY, USA, 1961.

4. Gehl, J. Life between Buildings: Using Public Space; The Danish Architectural Press: Copenhagen, Denmark, 1987.

5. Rogers, R. Przedmowa. Preface. In Miasta sa dla Ludzi [Cities are for the People]; Gehl, J., Ed.; RAM: Kraków, Poland, 2014; Volume IX.

6. Montgomery, J. Making a city: Urbanity, vitality and urban design. J. Urban Des. 1998, 3, 93-116. [CrossRef]

7. Childs, M.C. Squares: A Public Place Design Guide for Urbanists; University of New Mexico: Albuquerque, NM, USA, 2004.

8. Czepczyński, M. Przestrzeń publiczna jako forma reprezentacji społeczności lokalnych. Między hibernacją a animacją centrów małych miast woj. pomorskiego. [Public Space as a Representation of Local Societies. Between Hibernation and Animation of Small Towns Centres of Pomorskie Voivodeship]. In Przestrzeń Publiczna Małych Miast; Heffner, K., Marszał, T., Eds.; KPZK PAN: Warsaw, Poland, 2012; Volume 144, pp. 7-19.

9. Carr, S.; Francis, M.; Rivlin, L.G.; Stone, A.M. Public Space; Cambridge University Press: Cambridge, UK, 1992.

10. Mandeli, K. Public space and the challenge of urban transformation in cities of emerging economies: Jeddah case study. Cities 2019, 95, 1-11. [CrossRef]

11. Gehl, J. Miasta Dla Ludzi [Cities are for the People], ttum. Szymon Nogalski; RAM: Cracow, Poland, 2014. 
12. Zhuang, J. Creating an Attractive Public Space for the Citizens-Ströget Street in Copenhagen, Demark, Shanxi Road Square in Nanjing, China; Blekinge Institute of Technology: Karlskrona, Sweden, 2008. Available online: https://www.diva-portal.org/smash/get/ diva2:829360/FULLTEXT01.pdf (accessed on 12 September 2021).

13. Wejchert, K. Przestrzeń wokół nas [The Space Around us]; Fibak Noma Press: Katowice, Poland, 1993.

14. Walzer, M. Pleasures and Costs of Urbanity. Dissent 1986, 33, 470-475.

15. Tibbalds, F. Making People-Friendly Towns: Improving the Public Environment in Towns and Cities; Harlow: Longman, UK, 1992.

16. Lorens, P. Tematyzacja przestrzeni publicznej jako wyraz dywersyfikacji struktury urbanistycznej miasta doby globalizacji. [Thematisation of Public Space as an Expression of the Diversification of the Urban Structure of the City in the Era of Globalization]. In Percepcja Wspótczesnej Przestrzeni Miejskiej; Madurowicz, M., Ed.; Uniwersytet Warszawski: Warsaw, Poland, 2007; pp. 83-92.

17. Zagroba, M.; Szczepańska, A.; Senetra, A. Analysis and Evaluation of Historical Public Spaces in Small Towns in the Polish Region of Warmia. Sustainability 2020, 12, 8356. [CrossRef]

18. Jędrzejczyk, D. Geografia Humanistyczna Miasta [Human Geography of City]; Wydawnictwo Akademickie Dialog: Warsaw, Poland, 2004.

19. Wẹcławowicz, G. Geografia Społeczna Miast. Zróżnicowania Społeczno-Przestrzenne [Social Geography of Cities. Socio-Spatial Differentiation]; Wydawnictwo Naukowe PWN: Warsaw, Poland, 2007.

20. Jałowiecki, B.; Łukowski, W. Szata Informacyjna Miasta [The Information Layout of the City]; Wydawnictwo Naukowe Scholar: Warsaw, Poland, 2008.

21. Maga-Jagielnicka, R. Standardy publicznych przestrzeni miejskich [Standards of Urban Public Space]. In Przestrzeń Publiczna Matych Miast; Heffner, K., Marszał, T., Eds.; KPZK PAN: Warsaw, Poland, 2012; Volume 144, pp. $33-46$.

22. Carmona, M.; Heath, T.; Oc, T.; Tiesdell, S. Public Places, Urban Spaces; Architectural Press: Oxford, UK, 2003.

23. Heffner, K.; Marszał, T. Przestrzeń Publiczna Małych Miast [Public Space of Small Towns]; KPZK PAN: Warsaw, Poland, 2012; Volume 144.

24. Litwińska, E. Czy można mówić o specyfice przestrzeni publicznych małego miasta? [Is it possible to talk about the specifics of public spaces in a small towns?]. In Przestrzeń Publiczna Matych Miast; Heffner, K., Marszał, T., Eds.; KPZK PAN: Warsaw, Poland, 2012; Volume 144, pp. 21-31.

25. Golędzinowska, A. Przeksztatcenia Przestrzeni Publicznej Miasta Średniej Wielkości w Warunkach Gospodarki Rynkowej w Polsce. [Transformations of the Public Space of a Medium-Sized City in the Conditions of the Market Economy in Poland]; Rozprawa doktorska, Wydział Architektury Politechniki Gdańskiej: Gdańsk, Poland, 2005. Available online: https://pbc.gda.pl/Content/50419/phd_ goledzinowska_anna2.pdf (accessed on 24 September 2021).

26. Nowicki, P. Zróżnicowanie przyrynkowej zabudowy i jej funkcji a typy genetyczne rynków w małych miastach województwa łódzkiego. [Diversity of Market Square Buildings and their Functions in the Context of Genetic Types of Market Squares in Small Cities of The Lodz Voivodeship]. Space Soc. Econ. 2019, 30, $29-49$.

27. Ilnicki, D. Przestrzenne Zróżnicowanie Poziomu Rozwoju Usług w Polsce. Teoretyczne i Praktyczne Uwarunkowania Badań, [Spatial Diversity of Service Development Level in Poland. Theoretical and Practical Determinants of Research]; Instytut Geografii i Rozwoju Regionalnego, Uniwersytet Wrocławski: Wrocław, Poland, 2009.

28. Gehl, J.; Gemzoe, L. New City Spaces, 3rd ed.; The Danish Architectural Press: Copenhagen, Denmark, 2000.

29. Gehl, J. Cities for People; Island Press: Washington, DC, USA, 2010.

30. Wojnarowska, A. Przestrzeń publiczna Uniejowa. [Public space of Uniejów]. Biuletyn Uniejowski 2015, 4, 25-44.

31. Wojnarowska, A. Jakość Przestrzeni Publicznej Centrum Miasta. Przykład Miast Średnich Regionu Łódzkiego [The Quality of Public Space in the City Center. An Example of Medium-sized Cities in the łódź Region]; Wyd. Uniwersytetu Łódzkiego: Łódź, Poland, 2017.

32. Bański, J.; Kamińska, W.; Mularczyk, M. The natural and migration movements versus population ageing in Poland's small towns. In The Routledge Handbook of Small Towns; Bański, J., Ed.; Routledge: New York, NY, USA, 2021; pp. $138-159$.

33. Szczepańska, A.; Pietrzyk, K. An Evaluation of Public Spaces with the Use of Direct and Remote Methods. Land 2020, 9, 419. [CrossRef]

34. Konecka-Szydłowska, B. Ocena przestrzeni publicznej małych miast aglomeracji poznańskiej. [Assessment of Public Spaces of Small Towns in the Poznań Agglomeration]. Problemy Rozwoju Miast 2016, 3, 5-12.

35. Kantor-Pietraga, I.; Krzysztofik, R.; Runge, J. Kontekst geograficzny i funkcjonalny kurczenia się małych miast w Polsce południowej. [Geographical and Functional Context of Shrinkage in Case of Small Towns of the Southern Poland]. In Ewolucja Funkcji matych Miast w Polsce; Heffner, K., Halama, A., Eds.; Uniwersytet Ekonomiczny w Katowicach: Katowice, Poland, 2012; pp. 9-24.

36. Kamińska, W. Kapitat Ludzki i Społeczny w Procesie Rozwoju Obszarów Wiejskich w Polsce. Przykład Województwa Świętokrzyskiego. [Human and Social Capital in the Process of Rural Development in Poland. Example of the Świętokrzyskie Voivodeship]; Wydawnictwo Uniwersytetu Humanistyczno-Przyrodniczego Jana Kochanowskiego w Kielcach: Kielce, Poland, 2011.

37. Cichocki, M. Współczesne przestrzenie publiczne w małych miastach na przykładzie miasta Tłuszcz. [Contemporary Public Spaces of Small Towns on the Example of Tłuszcz]. Urban Dev. Issues 2020, 66, 197-206. [CrossRef]

38. Zuzańska-Żyśko, E. Koziegłowy-miasto sukcesu gospodarczego. [Koziegłowy-City of the Economic Success]. In Nowoczesne Instrumenty Polityki Rozwoju Lokalnego_Zastosowanie i Efekty w Małych Miastach; Heffner, K., Twardzik, M., Eds.; Wydawnictwo Uniwersytetu Ekonomicznego: Katowice, Poland, 2013. 
39. Dymek, D.; Jóźwik, J. Kształtowanie placów miejskich na przykładzie miast województwa lubelskiego. [Shaping Town Squares on the Example of the Towns of Lubelskie Voivodeship]. Ann. Univ. Mariae Curie-Skłodowska Lub. Pol. 2021, 76, 1-28.

40. Boryczka, E. Rewitalizacja miast. [Urban Revitalization]. In EkoMiasto. Zarzadzanie. Zrównoważony, Inteligentny i Partycypacyjny Rozwój Miasta; Przygodzki, Z., Ed.; Wydawnictwo Uniwersytetu Łódzkiego: Łódź, Poland, 2016; pp. 167-193.

41. Wendt, J. Przestrzenne Zróżnicowanie i Uwarunkowania Przenikania Systemu Demokratycznego w Polsce $i$ w Rumunii. [Spatial Differentiation and Conditions for the Penetration of the Democratic System in Poland and Romania]; Carta Blanca: Warsaw, Poland, 2004.

42. Wendt, J. Wymiar Przestrzenny Struktur i Aktywność Społeczeństwa Obywatelskiego w Polsce [Spatial Dimension of Structures and Activity of the Civil Society in Poland]; IGiPZ PAN: Warsaw, Poland, 2007.

43. Wysocki, M. Dostępna Przestrzeń Publiczna. Samorząd Równych Szans [Accessible Public Space. Self-Government of Equal Opportunities]; Fundacja Instytut Rozwoju Regionalnego: Cracow, Poland, 2009.

44. Heffner, K.; Halama, A. (Eds.) Ewolucja Funkcji Matych Miast w Polsce [Evolution of the Functions of Small Towns in Poland]; Studia Ekonomiczne; Zeszyty Wydziałowe Naukowe Uniwersytetu Ekonomicznego w Katowicach: Katowice, Poland, 2012.

45. Kudełko, J.; Zioło, Z. Funkcje małych miast w przestrzeni rolniczej [Functions of Small Towns in the Agricultural Space]. Studia Obszarów Wiejskich 2006, 11, 39-58.

46. Marszał, T. (Ed.) Funkcja Przemysłowa Małych Miast [Industrial Function of Small Towns]; Wydawnictwo Uniwersytetu Łódzkiego: Łódź, Poland, 2009.

47. Nowak, J.; Witeska, M. Scenariusze Rozwoju Matych Miast [Scenarios for the Development of Small Towns]; Polski Instytut Ekonomiczny: Warsaw, Poland, 2019.

48. Kamińska, W. Rewitalizacja i zróżnicowanie funkcjonalne przestrzeni publicznej w małych miastach. Przykład rynku w Chęcinach w woj. świętokrzyskim [Revitalization and Functional Diversification of Public Space in Small Towns. An Example of the Square in Chẹciny in the Province Świętokrzyskie]. Studia Ślaskie 2021, 88, 27-42.

49. Kamińska, W.; Mularczyk, M. Rynki jako przestrzeń publiczna w nowych małych miastach. Przykład województwa świętokrzyskiego [Squers as Public Space in New Small Towns. An Example of the Świętokrzyskie Voivodeship]. In Proceedings of the 36 Seminarium Geografii Wsi, Olsztyn, Poland, 21-22 June 2021.

50. Brol, R. Procesy urbanizacji wsi polskiej. [The Processes of Urbanization of the Polish Countryside]. In Prace Naukowe Akademii Ekonomicznej we Wrocławiu. Seria: Monografie i Opracowania; Wydawnictwo Uniwersytetu Ekonomicznego we Wrocławiu: Wrocław, Poland, 1996; p. 739.

51. Kamińska, W. Urbanizacja Obszarów Wiejskich Województwa Świętokrzyskiego [Urbanization of Rural Areas in the Świętokrzyskie Voivodeship]; Wydawnictwo Uniwersytetu Humanistyczno-Przyrodniczego Jana Kochanowskiego w Kielcach: Kielce, Poland, 2010.

52. Bagiński, E. Małe Miasta w Strukturze Osiedleńczej Polski [Small Towns in the Settlement Structure of Poland]; Oficyna Wydawnicza Politechniki Wrocławskiej: Wrocław, Poland, 1988.

53. Saterus, P. Leksykon Urbanistyki i Planowania Przestrzennego [Lexicon of Town Planning and Spatial Planning]; BEL Studio: Warsaw, Poland, 2013.

54. Sokołowski, D. Urbanizacja wsi na przykładzie miast zdegradowanych województwa świętokrzyskiego. [Urbanization of Villages on the Example of Former Towns in the Świętokrzyskie Voivodeship]. Studia Obszarów Wiejskich 2015, 37, 195-216. [CrossRef]

55. Mularczyk, M. Regionalny System Miast—Hierarchia czy Poziomy Układ Sieciowy? Przykład Województwa Świętokrzyskiego [Regional System of Cities—Hierarchy or Horizontal Network System? An Example of the Świętokrzyskie Voivodeship]; Wydawnictwo Uniwersytetu Jana Kochanowskiego: Kielce, Poland, 2016.

56. Kot, R. The Point Bonitation Method for Evaluating Geodiversity: A Guide with Examples (Polish Lowland). Geografiska Annaler Ser. A Phys. Geogr. 2015, 97, 375-393. [CrossRef]

57. Mueller, L.; Schindler, U.; Mirschel, W.; Shepherd, T.G.; Ball, B.C.; Helming, K.; Rogasik, J.; Eulenstein, F.; Wiggering, H. Assessing the Productivity Function of Soils. Agron. Sustain. Dev. 2010, 30, 601-614. [CrossRef]

58. Bastian, O.; Meyer, B.C.; Panse, E.; Röder, M.; Syrbe, R.-U. Landscape Assessment. In Development and Perspectives of Landscape Ecology; Bastian, O., Steinhardt, U., Eds.; Kluwer: Dordrecht, The Netherlands, 2002; pp. 205-255.

59. Rucińska, D.; Zagrzejewska, M. The Point Bonitation Method and its Adaptation in Risk Studies: A Case Study in Sri Lanka's Cities in the Coastal Zone. Int. J. Environ. Res. Public Health 2021, 18, 2060. [CrossRef] [PubMed]

60. Reynard, E.; Fontana, G.; Kozlik, L.; Scapozza, C. A Method for Assessing 'Scientific' and 'Additional Values' of Geomorphosites. Geogr. Helvatica 2007, 62, 148-158. [CrossRef]

61. Kowalska, K. An Attempt at an Integrated Assessment of the Tourism Attractiveness of a Region: The Example of North Karelia (Finland). Tourism 2012, 22, 21-28. [CrossRef]

62. Richling, A.; Solon, J. Ekologia Krajobrazu [Landscape Ecology]; PWN: Warsaw, Poland, 2011.

63. Okros, A.; Mihut, C.; Nită, L.D. Yield Capacity of the Soils in Recas, Viticulture Centre, Timis Country. Res. J. Agric. Sci. 2012, 44, 95-101.

64. Musielok, Ł.; Drewnik, M.; Stolarczyk, M.; Gus, M.; Bartkowiak, S.; Kożyczkowski, K.; Lasota, J.; Motak, A.; Szczechowska, K.; Watty, M. Rates of Anthropogenic Transformation of Soils in the Botanical Garden of Jagiellonian University in Kraków (Poland). Catena 2018, 170, 272-282. [CrossRef] 
65. Koźma, J. Metodyka waloryzacji przestrzennej pokrycia terenu i obiektów ochrony przyrody na potrzeby oceny konfliktowości potencjalnej eksploatacji kopalin w obszarach perspektywicznych [Methodology of Spatial Valorization of Land Cover and Objects of Nature Conservation in Assessment of Potential Conflict of Exploitation of Minerals in Prospective Areas]. Przeglad Geologiczny 2015, 63, 581-588.

66. Fassoulas, C.; Mouriki, D.; Dimitriou-Nikolakis, P.; Iliopoulos, G. Quantitative Assessment of Geotopes as an Effective Tool for Geoheritage Management. Geoheritage 2012, 4, 177-193. [CrossRef]

67. Martínez-Graña, A.M.; Goy, J.L.; Cimarra, C.A. A Virtual Tour of Geological Heritage: Valourising Geodiversity Using Google Earth and R Code. Comput. Geosci. 2013, 61, 83-93. [CrossRef]

68. Rocha, J.; Brilha, J.; Henriques, M.H. Assessment of the Geological Heritage of Cape Mondego Natural Monument (Central Portugal). Proc. Geol. Assoc. 2014, 125, 107-113. [CrossRef]

69. Zwoliński, Z.; Najwer, A.; Giardino, M. Methods for Assessing Geodiversity. In Geoheritage. Assessment, Protection, and Management; Reynard, E., Brilha, J., Eds.; Elsevier: Chennai, India, 2018; pp. 27-52.

70. Turel, H.S.; Yigit, E.M.; Altug, I. Evaluation of Elderly People's Requirements in Public Open Spaces: A Case Study in Bornova District (Izmir, Turkey). Build. Environ. 2007, 42, 2035-2045. [CrossRef]

71. Perovic, S.; Kurtovic Folic, N. Visual Perception of Public Open Spaces in Niksic. Procedia Soc. Behav. Sci. 2012, 68, 921-933. [CrossRef]

72. Micek, M.; Staszewska, S. Urban and Rural Public Spaces: Development Issues and Qualitative Assessment. Bull. Geogr. Socio-Econ. Ser. 2019, 45, 75-93. [CrossRef]

73. Kucina, W. Projekt Waloryzacji Terenu Nadleśnictwa pod Kątem Turystycznej Atrakcyjności Środowiska [Project of Valorization of the Area of Forest District in Terms of Tourist Attractiveness of the Environment]. Ośrodek Rozwojowo-Wdrożeniowy Lasów Państwowych w Bedoniu; 2006. Available online: www.bedon.lasy.gov.pl/orwlp/turystyka/Prace_naukowe (accessed on 12 September 2021).

74. Rutkiewicz, A.; Stolarski, G.; Sot, H. Turystyczna atrakcyjność nadleśnictwa-Studium przypadku. [Tourist Attractiveness of a Forest District-A Case Study]. Studia i Materiaty CEPL w Rogowie 2015, 17, 187-193.

75. Ustawa o Planowaniu Przestrzennym z 27 marca 2003 [The Act on Spatial Planning]. Dz. U. nr 80, poz. 717. Available online: https: / / isap.sejm.gov.pl/isap.nsf/DocDetails.xsp?id=WDU20030800717 (accessed on 28 November 2021).

76. Wejchert, K. Miasteczka Polskie Jako Zagadnienie Urbanistyczne [Polish Towns as an Urban Issue]; Zakład Architektury Polskiej i Historii Sztuki Politechniki Warszawskiej: Warsaw, Poland, 1947.

77. Kosiński, W. Miasto i Piękno Miasta [The City and the Beauty of the City]; Politechnika Krakowska: Cracow, Poland, 2011.

78. Podciborski, T.; Jęrzejewska, K. Ocena stanu ładu przestrzennego terenów zabudowy wsi warmińskiej. [Assessment of the Status of the Spatial Order of Built-Up Areas in Villages in Warmia]. Acta Sci. Polonorum. Adm. Locorum 2011, 10, 63-79.

79. Górczyńska, M. Wskaźniki zagospodarowania i ładu przestrzennego w miastach i na obszarach silnie zurbanizowanych, [Indicators for the Assessment of Spatial Organization and Spatial Order in Cities and in Urbanized Areas]. Biuletyn KPZK PAN 2013, 252, 87-109.

80. Maliszowa, B. Śródmieście. Wybrane Zagadnienia Planowania [Downtown. Selected Planning Issues]; Arkady: Warsaw, Poland, 1974.

81. Springer, F. Wanna z Kolumnada. Reportaże o Polskiej Przestrzeni [Colonnaded Bathtub. Reportages about Polish Space]; Wyd. Czarne: Wołowiec, Poland, 2013.

82. Ustawa Prawo budowlane z 7 lipca 1994 [Construction Act]. Dz.U. nr 89, poz. 1333. Available online: https://isap.sejm.gov.pl/isap. nsf/DocDetails.xsp?id=WDU19940890414 (accessed on 28 November 2021).

83. Jałowiecki, B.; Szczepański, M. Miasto i Przestrzeń w Perspektywie Socjologicznej [City and Space in a Sociological Perspective]; Wydawnictwo Naukowe Scholar: Warsaw, Poland, 2006.

84. Encyklopedia Powszechna [Universal Encyclopedia]; Wydawnictwo Naukowe PWN: Warsaw, Poland, 2009.

85. Eco, U. History of Beauty; Rizzoli International Publications: New York, NY, USA, 2005.

86. Bierwiaczonek, K. Społeczne Znaczenie Miejskich Przestrzeni Publicznych [Social Importance of Urban Public Spaces]; Wyd. Uniwersytetu Śląskiego: Katowice, Poland, 2016.

87. Zipser, T. Zasady Planowania Przestrzennego [Principles of Spatial Planning]; Politechnika Wrocławska: Wroclaw, Poland, 1983.

88. Szczepański, M.S. Miasto Socjalistyczne i Świat Społeczny Jego Mieszkańców [A Socialist City and the Social World of Its Inhabitants]; Europejski Instytut Rozwoju Lokalnego i Regionalnego: Warsaw, Poland, 1991.

89. Lattman, P. The Origins of Justice Stewart's "I Know It When I See It". LawBlog at The Wall Street Journal Online. Wall Street Journal. 27 September 2007. Available online: https:/ / www.wsj.com/articles/BL-LB-4558 (accessed on 3 November 2021).

90. Gołaszewska, M. Zarys Estetyki. [Outline of Aesthetics]; PWN: Warsaw, Poland, 1984.

91. Groeger, L. Przestrzeń publiczna małego miasta w opinii mieszkańców (Przykład Łasku) [Public Space of a Small Town in the Opinion of the Inhabitants (Example of Łask)]. In Przestrzeń Publiczna Małych Miast; Heffner, T., Marszał, T., Eds.; KPZK PAN: Warsaw, Poland, 2012; Volume 144, pp. 123-134.

92. Poradnik o Przestrzeniach Publicznych. Studium Ogólnomiejskich Przestrzeni Publicznych [A Guidebook on Public Spaces. Study of City-Wide Public Spaces]. Gdańsk. 2014. Available online: https:/ /www.brg.gda.pl/planowanie-przestrzenne/inneopracowania-urbanistyczne/62-sopp-studium-ogolnomiejskich-przestrzeni-publicznych (accessed on 10 September 2021). 
93. Łaguna, D. Przekształcenia przestrzeni publicznej w miastach położonych na szlaku Wielkich Jezior Mazurskich. [Transformations of the Public Space in Towns Located on the Route of the Great Masurian Lakes]. In Przestrzeń Publiczna Matych Miast; Heffner, K., Marszał, T., Eds.; Studia KPZK PAN: Warsaw, Poland, 2012; Volume 144, pp. 81-98.

94. Kozłowski, S.; Borowska, M. Rewitalizacja historycznego centrum Łęczycy, [Revitalization of the Historic Center of Łęczyca]. In Przestrzeń Publiczna Małych Miast; Heffner, K., Marszał, T., Eds.; Studia KPZK PAN: Warsaw, Poland, 2012; Volume 144, pp. 111-122.

95. Lorens, P. Porządek architektoniczny i urbanistyczny jako element przestrzennego zagospodarowania kraju. [Architectural and urban order as an element of spatial development of the country]. Studia Regionalne i Lokalne 2005, 6, 21-50.

96. Holland, C.; Clark, A.; Katz, J.; Peace, S. Social Interactions in Urban Public Places; Bristol University Press: Bristol, UK, 2007.

97. Whyte, W.H. The Social Life of Small Urban Spaces; Conservation Foundation: Washington, DC, USA, 1980.

98. Ustawa o Drogach Publicznych z 21 marca 1985 [Public Roads Act]. Dz. U. nr 14, poz. 60. Available online: http:/ /isap.sejm.gov.pl/ isap.nsf/DocDetails.xsp?id=wdu19850140060 (accessed on 28 November 2021).

99. Trancik, R. Findings Lost Spaces: Theories of Urban Design; Van Nostrand Reinhold: New York, NY, USA, 1986.

100. Oktay, D. The Quest for Urban Identity in the Changing Context of the City: Northern Cyprus. Cities 2002, 19, 31-41. [CrossRef]

101. Wilczyński, R. Przestrzeń wiejska [Rural Space]. In Przestrzeń życia Polaków; Stowarzyszenie Architektów Polskich SARP: Warsaw, Poland, 2014; pp. 37-64.

102. Watson, D.; Plattus, A.; Shibley, R. (Eds.) Time-Saver Standards for Urban Design; The McGraw-Hill Companies: New York, NY, USA, 2003. 